\title{
LEVEL II SCOUR ANALYSIS FOR BRIDGE 5 (STOCTH00360005) on TOWN HIGHWAY 36, crossing STONY BROOK, STOCKBRIDGE, VERMONT
}

\section{Open-File Report 98-XXX}

Prepared in cooperation with

VERMONT AGENCY OF TRANSPORTATION

and

FEDERAL HIGHWAY ADMINISTRATION

U.S. Department of the Interior

U.S. Geological Survey

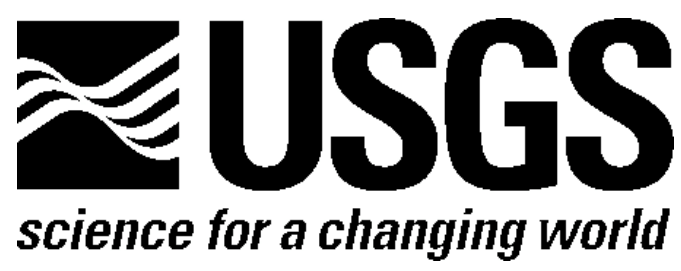




\section{LEVEL II SCOUR ANALYSIS FOR BRIDGE 5 (STOCTH00360005) on TOWN HIGHWAY 36, crossing STONY BROOK, STOCKBRIDGE, VERMONT \\ By LORA K. STRIKER AND MATTHEW A. WEBER \\ U.S. Geological Survey Open-File Report 98-XXX}

Prepared in cooperation with

VERMONT AGENCY OF TRANSPORTATION

and

FEDERAL HIGHWAY ADMINISTRATION

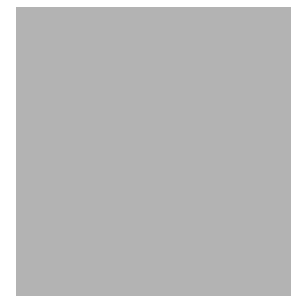




\title{
U.S. DEPARTMENT OF THE INTERIOR BRUCE BABBITT, Secretary
}

\author{
U.S. GEOLOGICAL SURVEY
}

Thomas J. Casadevall, Acting Director

For additional information write to:

District Chief

U.S. Geological Survey 361 Commerce Way

Pembroke, NH 03275-3718
Copies of this report may be purchased from:

U.S. Geological Survey

Branch of Information Services

Open-File Reports Unit

Box 25286

Denver, CO 80225-0286 


\section{CONTENTS}

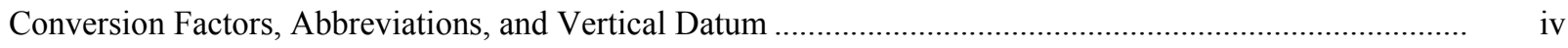

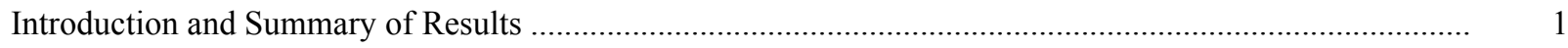

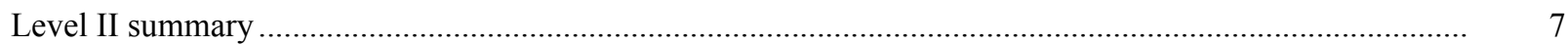

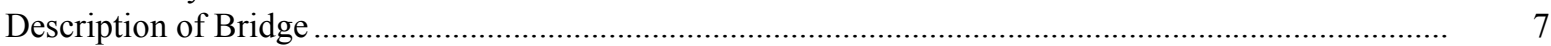

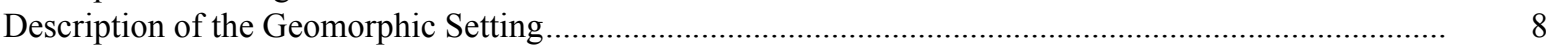

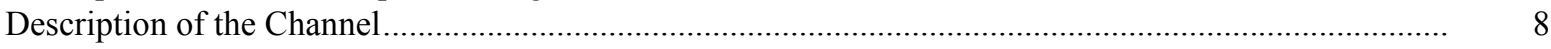

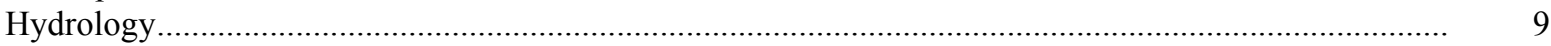

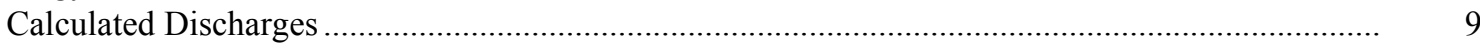

Description of the Water-Surface Profile Model (WSPRO) Analysis .................................................... 10

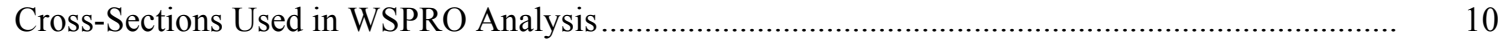

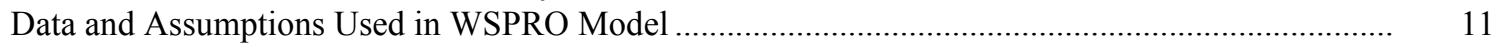

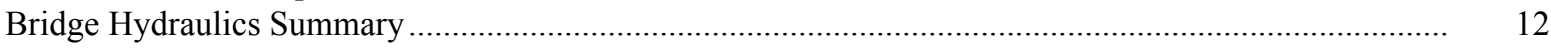

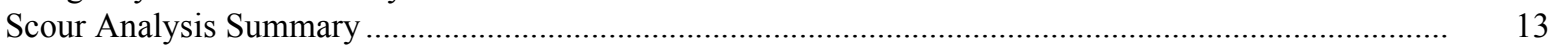

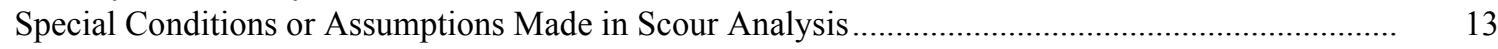

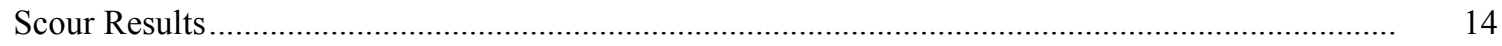

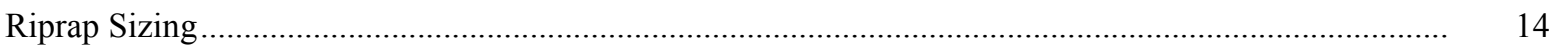

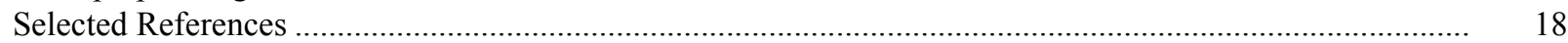

Appendices:

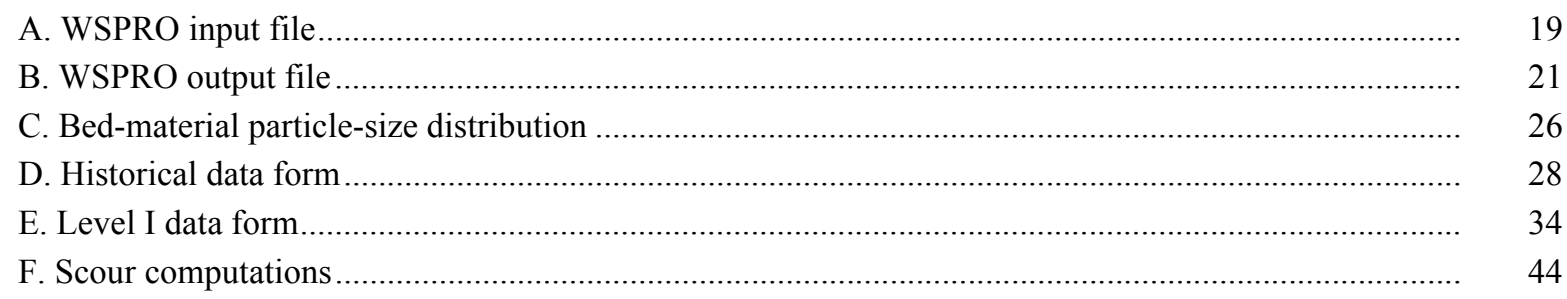

\section{FIGURES}

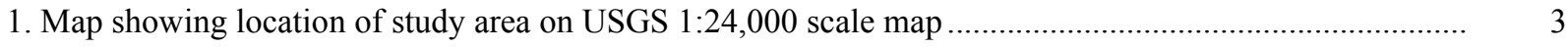

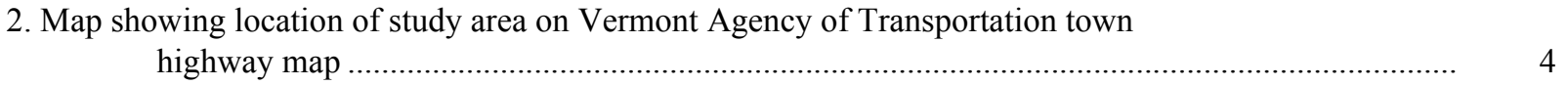

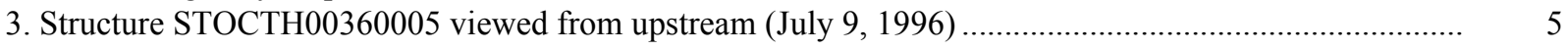

4. Downstream channel viewed from structure STOCTH00360005 (July 9, 1996).................................... 5

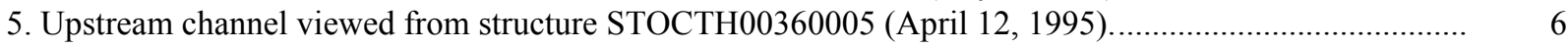

6. Structure STOCTH00360005 viewed from downstream (April 12, 1995)............................................... 6

7. Water-surface profiles for the 100- and 500-year discharges at structure

STOCTH00360005 on Town Highway 36, crossing Stony Brook, Stockbridge, Vermont.

8. Scour elevations for the 100- and 500-year discharges at structure

STOCTH00360005 on Town Highway 36, crossing Stony Brook,

Stockbridge, Vermont.

\section{TABLES}

1. Remaining footing/pile depth at abutments for the 100-year discharge at structure STOCTH00360005 on Town Highway 36, crossing Stony Brook,

Stockbridge, Vermont....

2. Remaining footing/pile depth at abutments for the 500-year discharge at structure

STOCTH00360005 on Town Highway 36, crossing Stony Brook,

Stockbridge, Vermont 


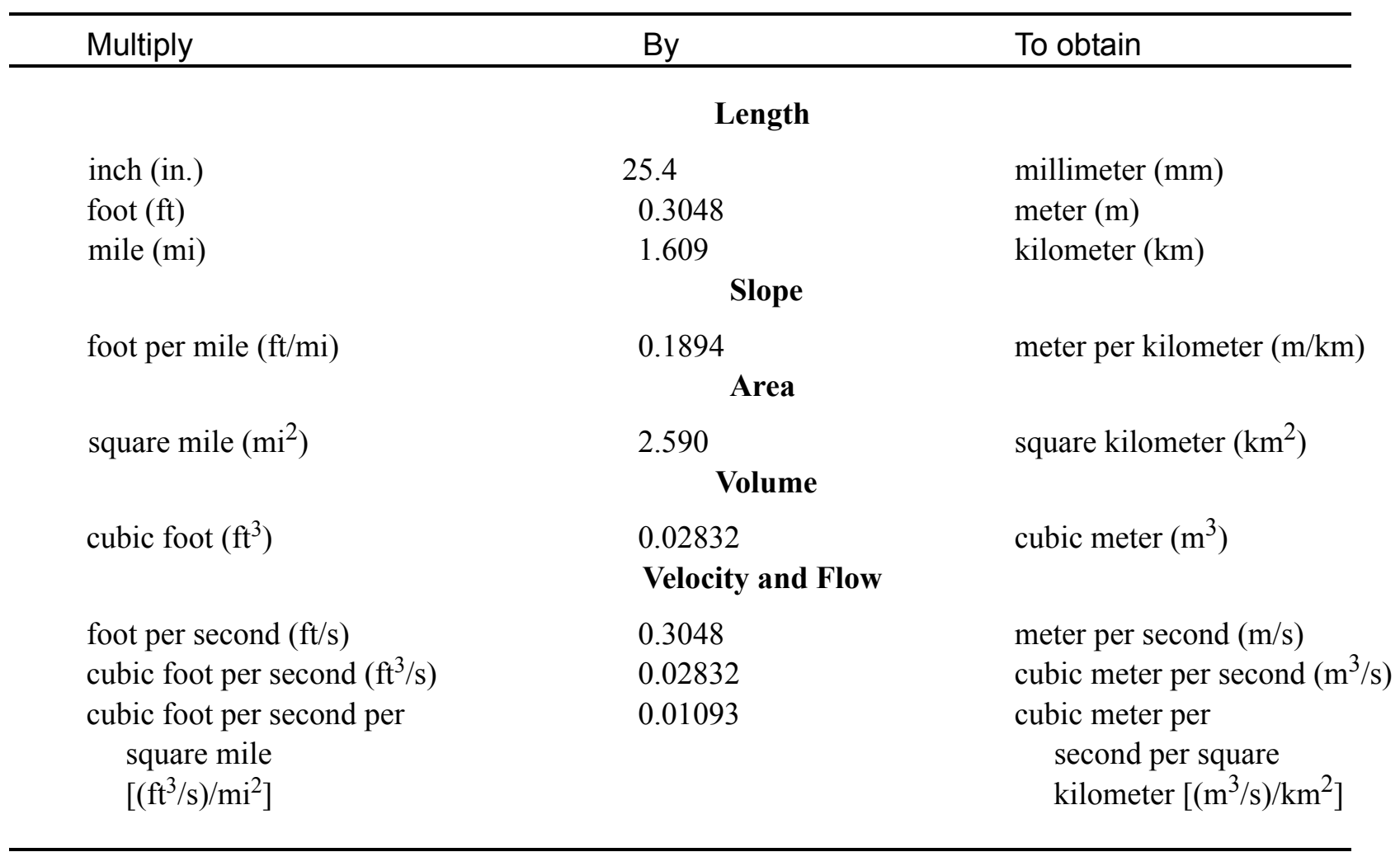

\section{OTHER ABBREVIATIONS}

\begin{tabular}{|c|c|c|c|}
\hline $\mathrm{BF}$ & bank full & LWW & left wingwall \\
\hline $\mathrm{cfs}$ & cubic feet per second & Max & maximum \\
\hline $\mathrm{D}_{50}$ & median diameter of bed material & $\mathrm{MC}$ & main channel \\
\hline DS & downstream & RAB & right abutment \\
\hline elev. & elevation & RABUT & face of right abutment \\
\hline $\mathrm{f} / \mathrm{p}$ & flood plain & $\mathrm{RB}$ & right bank \\
\hline $\mathrm{ft}^{2}$ & square feet & $\mathrm{ROB}$ & right overbank \\
\hline $\mathrm{ft} / \mathrm{ft}$ & feet per foot & RWW & right wingwall \\
\hline FEMA & Federal Emergency Management Agency & $\mathrm{TH}$ & town highway \\
\hline FHWA & Federal Highway Administration & UB & under bridge \\
\hline JCT & junction & US & upstream \\
\hline LAB & left abutment & USGS & United States Geological Survey \\
\hline LABUT & face of left abutment & VTAOT & Vermont Agency of Transportation \\
\hline LB & left bank & WSPRO & water-surface profile model \\
\hline LOB & left overbank & $\mathrm{yr}$ & year \\
\hline
\end{tabular}

In this report, the words "right" and "left" refer to directions that would be reported by an observer facing downstream. Sea level: In this report, "sea level" refers to the National Geodetic Vertical Datum of 1929-- a geodetic datum derived from a general adjustment of the first-order level nets of the United States and Canada, formerly called Sea Level Datum of 1929.

In the appendices, the above abbreviations may be combined. For example, USLB would represent upstream left bank. 


\title{
LEVEL II SCOUR ANALYSIS FOR BRIDGE 5 (STOCTH00360005) ON TOWN HIGHWAY 36, CROSSING STONY BROOK, STOCKBRIDGE, VERMONT
}

\author{
By Lora K. Striker and Matthew A. Weber
}

\section{INTRODUCTION AND SUMMARY OF RESULTS}

This report provides the results of a detailed Level II analysis of scour potential at structure STOCTH00360005 on Town Highway 36 crossing Stony Brook, Stockbridge, Vermont (figures 1-8). A Level II study is a basic engineering analysis of the site, including a quantitative analysis of stream stability and scour (U.S. Department of Transportation, 1993). Results of a Level I scour investigation also are included in appendix E of this report. A Level I investigation provides a qualitative geomorphic characterization of the study site. Information on the bridge, gleaned from Vermont Agency of Transportation (VTAOT) files, was compiled prior to conducting Level I and Level II analyses and is found in appendix D.

The site is in the Green Mountain section of the New England physiographic province in central Vermont. The $23.0-\mathrm{mi}^{2}$ drainage area is in a predominantly rural and forested basin. In the vicinity of the study site, the surface cover is forest on the left and right banks downstream and left bank upstream, while the right bank upstream is pasture with some shrubs and brush.

In the study area, Stony Brook has an incised, sinuous channel with a slope of approximately $0.01 \mathrm{ft} / \mathrm{ft}$, an average channel top width of $109 \mathrm{ft}$ and an average bank height of $11 \mathrm{ft}$. The channel bed material is predominantly gravel with a median grain size $\left(\mathrm{D}_{50}\right)$ of $71.7 \mathrm{~mm}(0.235 \mathrm{ft})$. The geomorphic assessment at the time of the Level I site visit on April 12, 1995, and Level II site visit on July 9, 1996, indicated that the reach was stable.

The Town Highway 36 crossing of Stony Brook is a 50-ft-long, one-lane bridge consisting of one 48-foot steel-beam span (Vermont Agency of Transportation, written communication, March 23, 1995). The opening length of the structure parallel to the bridge face is $46.3 \mathrm{ft}$. The bridge is supported by a vertical, concrete abutment on the left and a vertical, concrete abutment with wingwalls on the right. The channel is skewed approximately 5 degrees to the opening while the opening-skew-to-roadway is 0 degrees. 
A scour hole $2.0 \mathrm{ft}$ deeper than the mean thalweg depth was observed during the Level I assessment along the left side of the channel at the downstream bridge face where the flow impacts a bedrock outcrop. Scour protection measures at the site included type-1 stone fill (less than 12 inches diameter) along the right bank upstream and at the upstream and downstream ends of the left abutment, type- 2 stone fill (less than 36 inches diameter) at the upstream end of the upstream right wingwall, and type-3 stone fill (less than 48 inches diameter) at the downstream end of the downstream right wingwall. Additional details describing conditions at the site are included in the Level II Summary and Appendices D and $\mathrm{E}$.

Scour depths and recommended rock rip-rap sizes were computed using the general guidelines described in Hydraulic Engineering Circular 18 (Richardson and Davis, 1995) for the 100- and 500-year discharges. Total scour at a highway crossing is comprised of three components: 1) long-term streambed degradation; 2) contraction scour (due to accelerated flow caused by a reduction in flow area at a bridge) and; 3 ) local scour (caused by accelerated flow around piers and abutments). Total scour is the sum of the three components. Equations are available to compute depths for contraction and local scour and a summary of the results of these computations follows.

Contraction scour for all modelled flows ranged from 2.0 to $3.2 \mathrm{ft}$. The worst-case contraction scour occurred at the 500-year discharge. Abutment scour ranged from 9.7 to $22.2 \mathrm{ft}$. The worst-case abutment scour occurred at the 500-year discharge. Additional information on scour depths and depths to armoring are included in the section titled "Scour Results". Scoured-streambed elevations, based on the calculated scour depths, are presented in tables 1 and 2. A cross-section of the scour computed at the bridge is presented in figure 8. Scour depths were calculated assuming an infinite depth of erosive material and a homogeneous particle-size distribution.

It is generally accepted that the Froehlich equation (abutment scour) gives "excessively conservative estimates of scour depths" (Richardson and Davis, 1995, p. 47). Usually, computed scour depths are evaluated in combination with other information including (but not limited to) historical performance during flood events, the geomorphic stability assessment, existing scour protection measures, and the results of the hydraulic analyses. Therefore, scour depths adopted by VTAOT may differ from the computed values documented herein. 


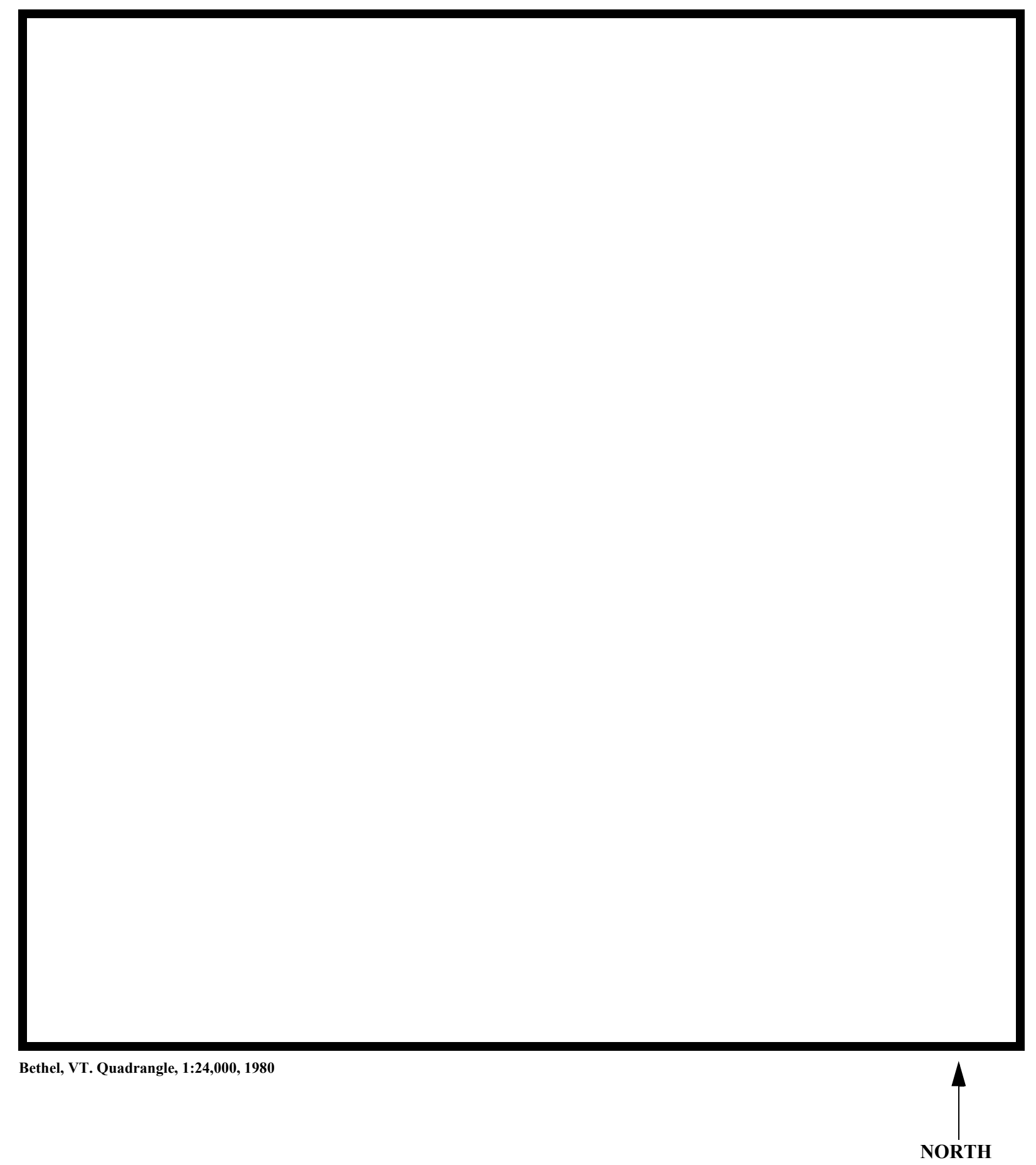

Figure 1. Location of study area on USGS 1:24,000 scale map. 
Figure 2. Location of study area on Vermont Agency of Transportation town highway map. 

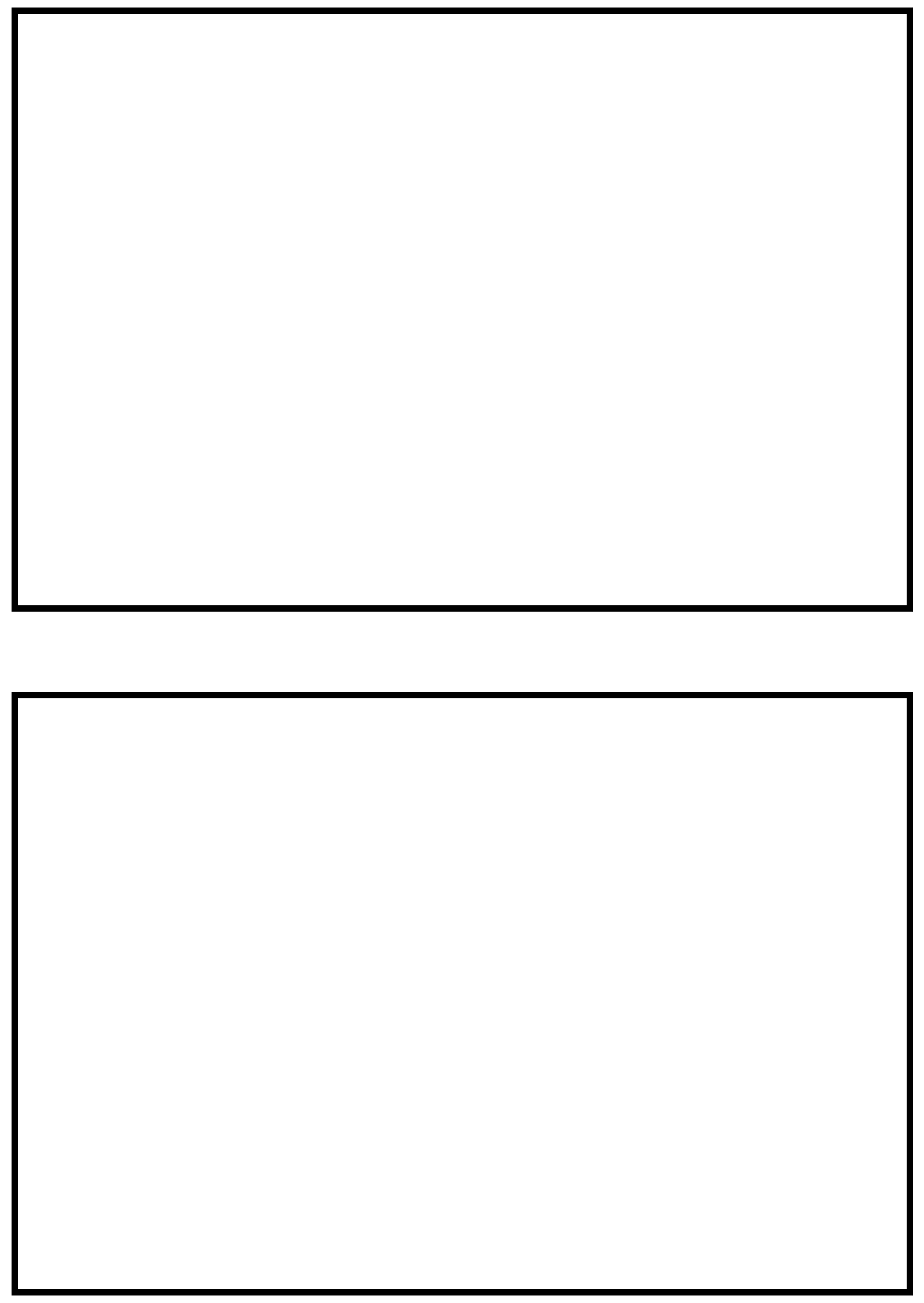

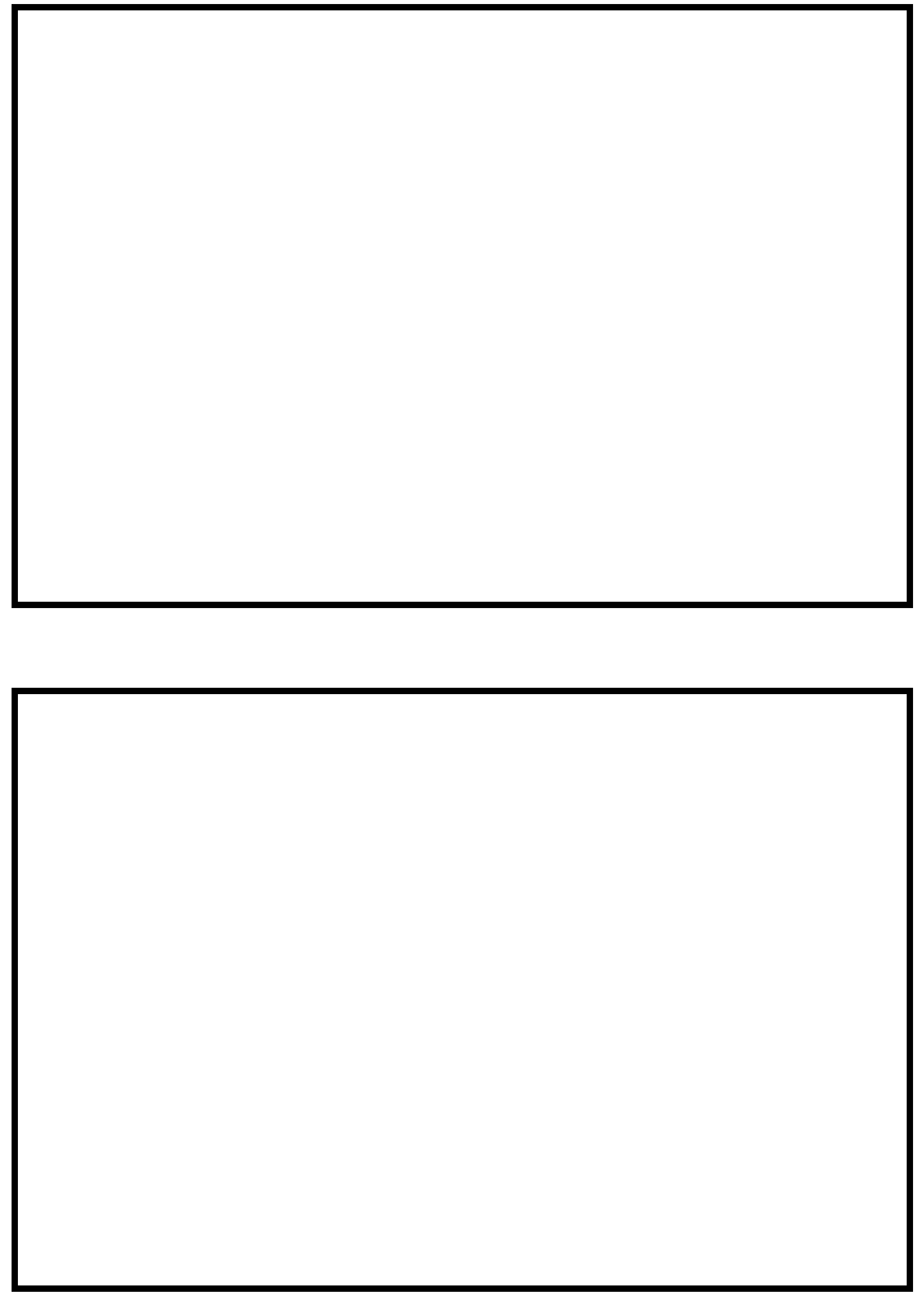


\section{LEVEL II SUMMARY}

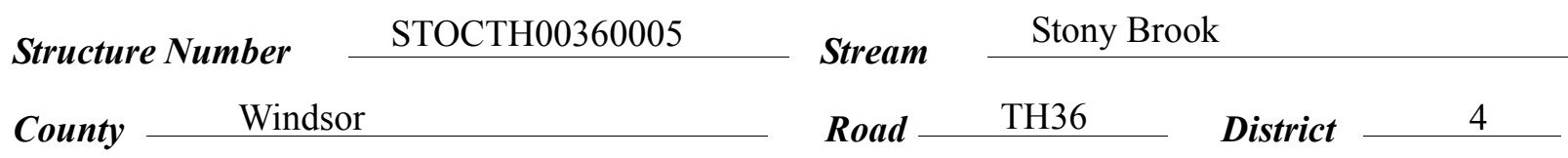

\section{Description of Bridge}

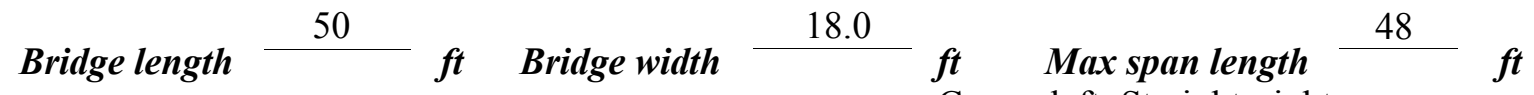
Alignment of bridge to road (on curve or straight)

Abutment type Vertical, concrete

Stone fill on abutment?

$$
\text { Yes }
$$

\section{Embankment type}

\section{Doto af incnortion} Type-1, at the upstream and downstream ends of the left abutment.
Sloping $04 / 12 / 95$

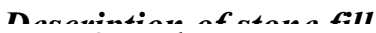

Type-2, at the upstream end of the upstream right wingwall. Type-3, at the downstream end of the downstream right wingwall.

The left abutment, the right abutment, and the right

upstream and downstream wingwalls are concrete.

\section{Yes}

Is bridge skewed to flood flow according to No ' survey? Angle

Debris accumulation on bridge at time of Level I or Level II site visit:

\begin{tabular}{|c|c|c|c|}
\hline & $\begin{array}{c}\text { Date of incmortion } \\
04 / 12 / 95 \\
\end{array}$ & $\begin{array}{l}\text { Percent of alommal } \\
\text { blocked hortzontally }\end{array}$ & $\begin{array}{l}\text { Percent of } 0 \\
\text { blocked verticatty }\end{array}$ \\
\hline & $07 / 09 / 96$ & 0 & 0 \\
\hline
\end{tabular}

Level II

Moderate. The upstream banks are heavily vegetated and are unstable beyond $200 \mathrm{ft}$ upstream.

Potential for debris

A large bedrock outcrop on the left bank at the downstream bridge face causes eddy currents Doscriho anv, foaturos noar ar at tho hridoo that mav, affoct flow, (includo ahsorvation dato) which have resulted in a $2.0 \mathrm{ft}$ scour hole, 04/12/95. 


\section{Description of the Geomorphic Setting}

General topography The channel is located within a moderate relief valley with a narrow flood plain.

Geomorphic conditions at bridge site: downstream (DS), upstream (US)

Date of inspection $\quad 04 / 12 / 95$

DS left: $\quad$ Moderately sloping overbank to narrow flood plain

DS right: $\quad$ Moderately sloping overbank

US left: $\quad$ Steep channel bank to an irregular overbank

US right: $\quad$ Steep channel bank to a narrow flood plain

\section{Description of the Channel}

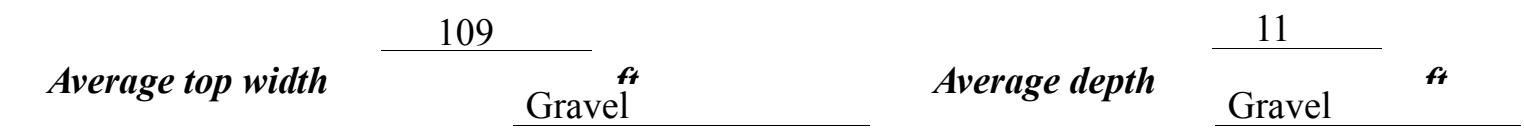

Predominant bed material

Bank material

Sinuous but stable

with semi-alluvial channel boundaries, local anabranching, random variation in width, and irregular point and lateral bars.

$04 / 12 / 95$

Vegetative cov' Trees änd brüsh

DS left: $\quad$ Trees and brush

DS right: $\quad$ Trees and brush

US left: $\quad$ Trees along the immediate banks with a pasture overbank

US right: $\quad$ Yes

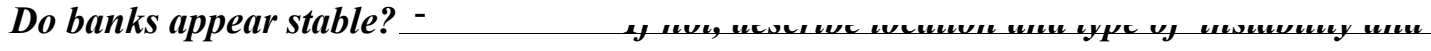
date of observation.

The assessment of

04/12/95 noted that flow conditions are influenced by a bedrock outcrop on the left bank Descrihe anv ohstructions in channel and date of ohservation. downstream. 


\title{
Hydrology
}

Drainage area $\stackrel{23.0}{\mathrm{mi}^{2}}$

Percentage of drainage area in physiographic provinces: (approximate)

Physiographic province/section

New England/Green Mountain
Percent of drainage area 100

\begin{abstract}
Is drainage area considered rural or urban?
Rural None.

urbanization:-

Describe any significant
\end{abstract}

Is there a USGS gage on the stream of interest?
USGS gage description

No

USGS gage description

USGS gage number

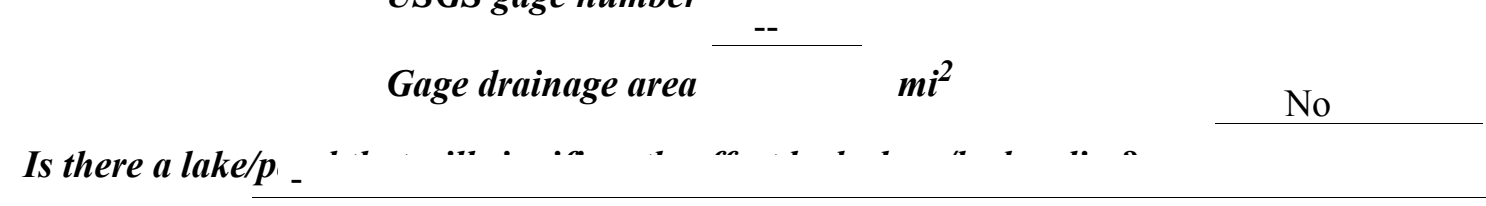

Is there a lake/p -

\begin{tabular}{llll}
4,260 & \multicolumn{2}{c}{ Calculated Discharges } & 5,750 \\
& $f t^{3} / s$ & $Q 500$ & $f t^{3} / s$
\end{tabular}

The 100- and 500-year discharges are based on a

drainage area relationship [(23.0/23.3) exp 0.67] with bridge number 9 in Stockbridge. Bridge

number 9 crosses Stony Brook downstream of this site and has flood frequency estimates

available from the VTAOT database (written communication, May 1995). The drainage area

above bridge number 9 is 23.3 square miles. These discharges are within a range defined by

several empirical methods (Benson, 1962; Johnson and Tasker, 1974; FHWA, 1983; Potter,

1957a\&b; Talbot, 1887) Each curve was extended graphically to the 500-year event. 


\section{Description of the Water-Surface Profile Model (WSPRO) Analysis}

Datum for WSPRO analysis (USGS survey, sea level, VTAOT plans)

USGS survey

Datum tie between USGS survey and VTAOT plans

None.

Description of reference marks used to determine USGS datum. $\quad$ RM1 is a chiseled X on

top of the curb at the downstream left corner of the bridge deck (elev. $500.80 \mathrm{ft}$, arbitrary survey

datum). RM2 is a chiseled X on top of the upstream end of the right abutment (elev. $499.92 \mathrm{ft}$,

arbitrary survey datum).

\section{Cross-Sections Used in WSPRO Analysis}

\begin{tabular}{cccl}
\hline${ }^{1}$ Cross-section & $\begin{array}{c}\text { Section } \\
\text { Reference } \\
\text { Distance } \\
\text { (SRD) in feet }\end{array}$ & $\begin{array}{c}{ }^{2} \text { Cross-section } \\
\text { development }\end{array}$ & \multicolumn{1}{c}{ Comments } \\
\hline EXITX & -46 & 1 & $\begin{array}{l}\text { Exit section } \\
\text { Downstream Full-valley } \\
\text { section (Templated from } \\
\text { FULLV }\end{array}$ \\
BRIDG & 0 & 2 & $\begin{array}{l}\text { BXidX) } \\
\text { Bridgection }\end{array}$ \\
RDWAY & 0 & 1 & $\begin{array}{l}\text { Road Grade section } \\
\text { Modelled Approach sec- } \\
\text { APPRO }\end{array}$ \\
\hline
\end{tabular}

${ }^{1}$ For location of cross-sections see plan-view sketch included with Level I field form, Appendix E.

For more detail on how cross-sections were developed see WSPRO input file. 


\section{Data and Assumptions Used in WSPRO Model}

Hydraulic analyses of the reach were done by use of the Federal Highway Administration's WSPRO step-backwater computer program (Shearman and others, 1986, and Shearman, 1990). The analyses reported herein reflect conditions existing at the site at the time of the study. Furthermore, in the development of the model it was necessary to assume no accumulation of debris or ice at the site. Results of the hydraulic model are presented in the Bridge Hydraulic Summary, appendix B, and figure 7.

Channel roughness factors (Manning's " $n$ ") used in the hydraulic model were estimated using field inspections at each cross section following the general guidelines described by Arcement and Schneider (1989). Final adjustments to the values were made during the modelling of the reach. Channel " $n$ " values for the reach ranged from 0.045 to 0.055 , and overbank " $\mathrm{n}$ " values ranged from 0.035 to 0.075 .

Normal depth at the exit section (EXITX) was assumed as the starting water surface. This depth was computed by use of the slope-conveyance method outlined in the user's manual for WSPRO (Shearman, 1990). The slope used was $0.0064 \mathrm{ft} / \mathrm{ft}$, which was estimated from points surveyed downstream of the bridge site on July 9, 1996.

The approach section (APPRO) was surveyed one bridge length upstream of the upstream face as recommended by Shearman and others (1986). This location provides a consistent method for determining scour variables.

For the 500-year discharge, WSPRO assumes critical depth at the bridge section. A supercritical model was developed for this discharge. After analyzing both the supercritical and subcritical profiles, it was determined that the water surface profile does pass through critical depth within the bridge opening. Thus, the assumption of critical depth at the bridge is a satisfactory solution. 


\section{Bridge Hydraulics Summary}

$\begin{array}{llll}\text { Average bridge embankment elevation } & 500.1 & f t \\ \text { Average low steel elevation } & 496.4 & \boldsymbol{f t}\end{array}$

100-year discharge $\quad 4,260 \quad \mathrm{ft}^{3} / \mathrm{s}$

Water-surface elevation in bridge opening $\quad 488.1 \quad f t$

Road overtopping? ___ No Discharge over road ___ $\quad \mathrm{ft}^{3} / \mathrm{s}$

\begin{tabular}{llc} 
Area of flow in bridge opening & 304 & $\boldsymbol{f t}^{2}$ \\
\cline { 2 - 2 } Average velocity in bridge opening & 14.0 & $\mathrm{ft} / \mathrm{s}$
\end{tabular}

Maximum WSPRO tube velocity at bridge $\quad 18.3 \mathrm{ft} / \mathrm{s}$

Water-surface elevation at Approach section with bridge 491.2

Water-surface elevation at Approach section without bridge $\quad 489.8$

Amount of backwater caused by bridge 1.4 it

500-year discharge $\quad 5,750 \quad \mathrm{ft}^{3} / \mathrm{s}$

Water-surface elevation in bridge opening $\quad 489.4 \mathrm{ft}$

Road overtopping? ___ No Discharge over road _ _ $\quad$\begin{tabular}{lll}
$\mathrm{i}^{3} / \mathrm{s}$ \\
\hline
\end{tabular}

Area of flow in bridge opening $\quad 361 \quad \boldsymbol{f t}^{2}$

Average velocity in bridge opening $15.9 \mathrm{ft} / \mathrm{s}$

Maximum WSPRO tube velocity at bridge 21.0 /s

Water-surface elevation at Approach section with bridge 493.4

Water-surface elevation at Approach section without bridge $\quad 491.2$

Amount of backwater caused by bridge $\quad 2.2, t$

Incipient overtopping discharge ___ -- $\mathrm{ft}^{3} / \mathrm{s}$

Water-surface elevation in bridge opening $\quad--\quad t$

Area of flow in bridge opening _ $\quad--\quad \mathrm{ft}^{2}$

Average velocity in bridge opening $\quad--\quad f t / s$

Maximum WSPRO tube velocity at bridge _-- $\mathrm{ft} / \mathrm{s}$

Water-surface elevation at Approach section with bridge

Water-surface elevation at Approach section without bridge

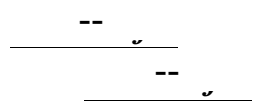

Amount of backwater caused by bridge _ 


\section{Scour Analysis Summary}

\section{Special Conditions or Assumptions Made in Scour Analysis}

Scour depths were computed using the general guidelines described in Hydraulic Engineering Circular 18 (Richardson and Davis, 1995). Scour depths were calculated assuming an infinite depth of erosive material and a homogeneous particle-size distribution. The results of the scour analysis are presented in tables 1 and 2 and a graph of the scour depths is presented in figure 8 .

Contraction scour for the 100- and 500-year discharges was computed by use of the Laursen clear-water contraction scour equation (Richardson and Davis, 1995, p. 32, equation 20). At this site, the 100- and 500-year discharges resulted in free surface flow. The streambed armoring depths computed suggest that armoring will not limit the depth of contraction scour.

Abutment scour was computed by use of the Froehlich equation (Richardson and Davis, 1995, p. 48, equation 28). Variables for the Froehlich equation include the Froude number of the flow approaching the embankments, the length of the embankment blocking flow, and the depth of flow approaching the embankment less any roadway overtopping. 


\section{Scour Results}

\section{0-yr discharge 500-yr discharge}

Contraction scour:

(Scour depths in feet)

Main channel

Live-bed scour

Clear-water scour

Depth to armoring

Left overbank

Right overbank

Local scour:

Abutment scour

Left abutment

9.7

11.0

18.9

$22.2-$

Right abutment

Pier scour

Pier 1

Pier 2

Pier 3

\section{Abutments:}

Left abutment

Right abutment

Piers:

Pier 1

Pier 2

Incipient overtopping discharge 


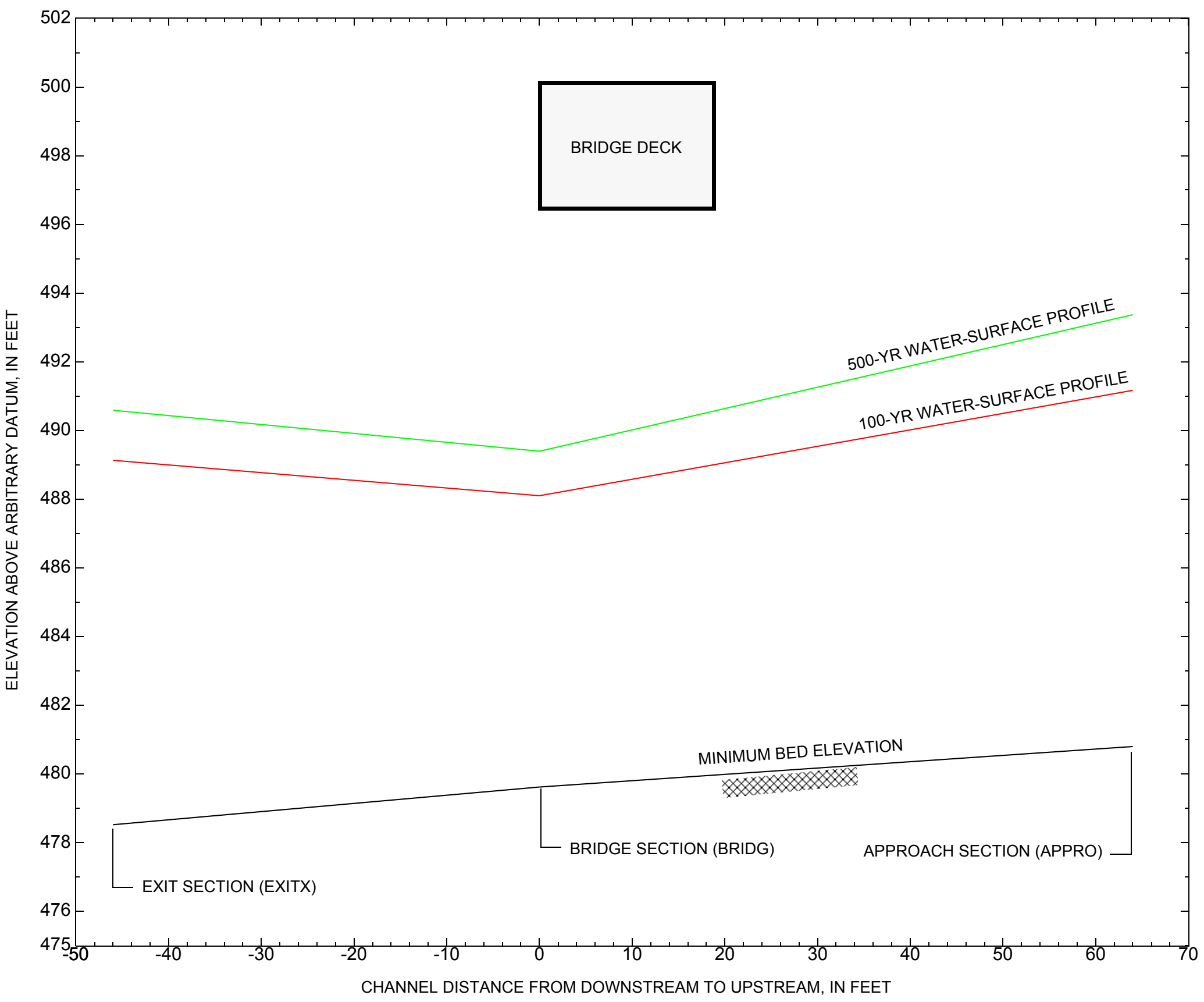

Figure 7. Water-surface profiles for the 100- and 500-yr discharges at structure STOCTH00360005 on Town Highway 36, crossing Stony Brook, Stockbridge, Vermont. 


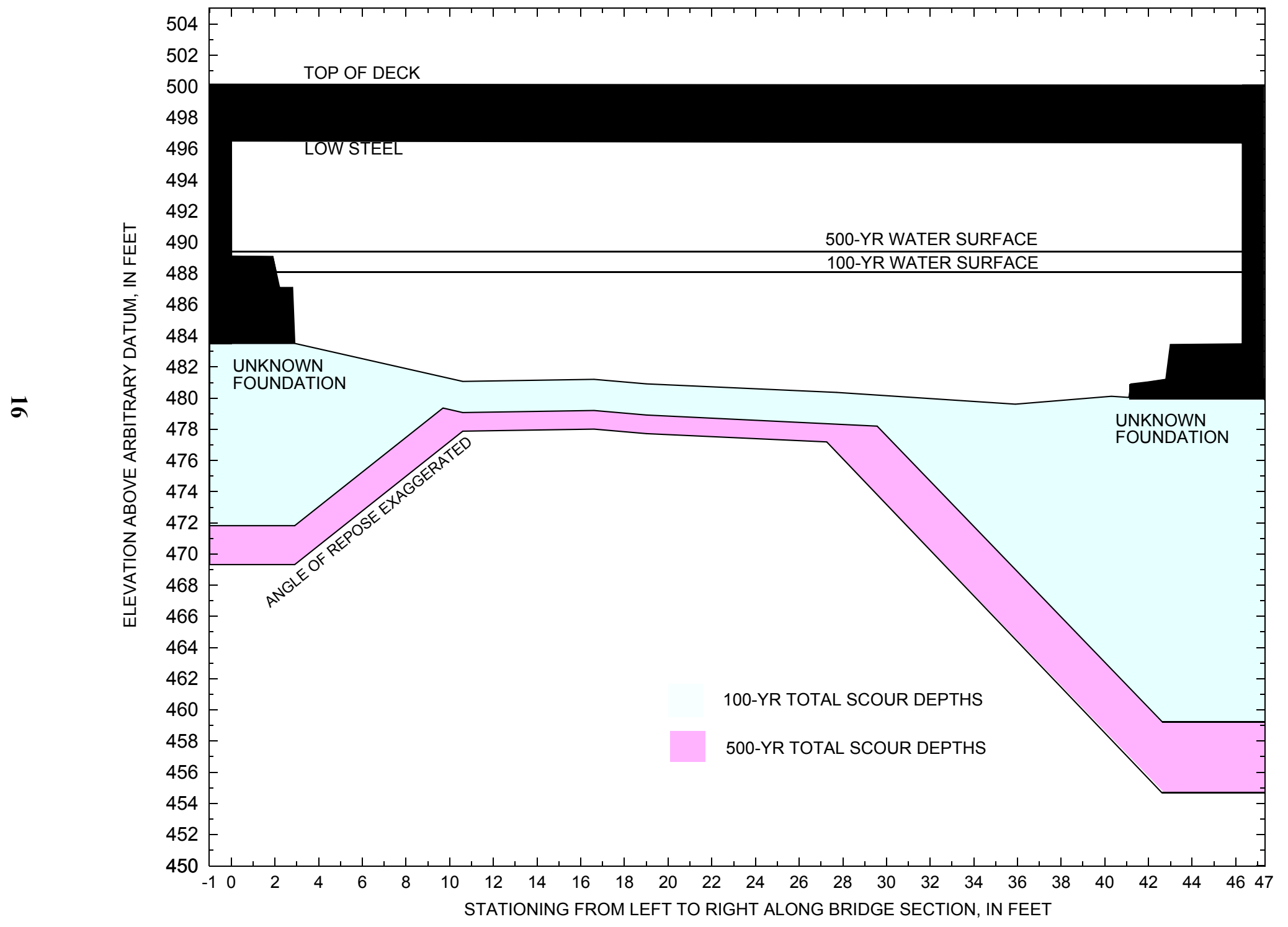

Figure 8. Scour elevations for the 100-yr and 500-yr discharges at structure STOCTH00360005 on Town Highway 36, crossing Stony Brook, Stockbridge, Vermont. 
Table 1. Remaining footing/pile depth at abutments for the 100-year discharge at structure STOCTH00360005 on Town Highway 36, crossing Stony Brook, Stockbridge, Vermont.

[VTAOT, Vermont Agency of Transportation; --, no data]

\begin{tabular}{|c|c|c|c|c|c|c|c|c|c|c|c|}
\hline Description & Station $^{1}$ & $\begin{array}{l}\text { VTAOT } \\
\text { minimum } \\
\text { low-chord } \\
\text { elevation } \\
\text { (feet) }\end{array}$ & $\begin{array}{l}\text { Surveyed } \\
\text { minimum } \\
\text { low-chord } \\
\text { elevation }{ }^{2} \\
\text { (feet) }\end{array}$ & $\begin{array}{c}\text { Bottom of } \\
\text { footing/pile } \\
\text { elevation }{ }^{2} \\
\text { (feet) }\end{array}$ & $\begin{array}{c}\text { Channel } \\
\text { elevation at } \\
\text { abutment/ } \\
\text { pier }^{2} \\
\text { (feet) }\end{array}$ & $\begin{array}{l}\text { Contraction } \\
\text { scour depth } \\
\text { (feet) }\end{array}$ & $\begin{array}{l}\text { Abutment } \\
\text { scour } \\
\text { depth } \\
\text { (feet) }\end{array}$ & $\begin{array}{l}\text { Pier } \\
\text { scour } \\
\text { depth } \\
\text { (feet) }\end{array}$ & $\begin{array}{l}\text { Depth of } \\
\text { total scour } \\
\text { (feet) }\end{array}$ & $\begin{array}{c}\text { Elevation of } \\
\text { scour }^{2} \\
\text { (feet) }\end{array}$ & $\begin{array}{c}\text { Remaining } \\
\text { footing/pile } \\
\text { depth } \\
\text { (feet) }\end{array}$ \\
\hline \multicolumn{12}{|c|}{100 -yr. discharge is 4,260 cubic-feet per second } \\
\hline Left abutment & 0.0 & -- & 496.5 & -- & 483.5 & 2.0 & 9.7 & -- & 11.7 & 471.8 & -- \\
\hline Right abutment & 46.3 & -- & 496.4 & -- & 480.0 & 2.0 & 18.9 & -- & 20.9 & 459.1 & -- \\
\hline
\end{tabular}

1.Measured along the face of the most constricting side of the bridge.

2.Arbitrary datum for this study.

Table 2. Remaining footing/pile depth at abutments for the 500-year discharge at structure STOCTH00360005 on Town Highway 36, crossing Stony Brook, Stockbridge, Vermont.

[VTAOT, Vermont Agency of Transportation; --, no data]

\begin{tabular}{|c|c|c|c|c|c|c|c|c|c|c|c|}
\hline Description & Station $^{1}$ & $\begin{array}{l}\text { VTAOT } \\
\text { minimum } \\
\text { low-chord } \\
\text { elevation } \\
\text { (feet) }\end{array}$ & $\begin{array}{c}\text { Surveyed } \\
\text { minimum } \\
\text { low-chord } \\
\text { elevation } \\
\text { (feet) }\end{array}$ & $\begin{array}{c}\text { Bottom of } \\
\text { footing/pile } \\
\text { elevation } \\
\text { (feet) }\end{array}$ & $\begin{array}{c}\text { Channel } \\
\text { elevation at } \\
\text { abutment/ } \\
\text { pier }^{2} \\
\text { (feet) }\end{array}$ & $\begin{array}{l}\text { Contraction } \\
\text { scour depth } \\
\text { (feet) }\end{array}$ & $\begin{array}{c}\text { Abutment } \\
\text { scour } \\
\text { depth } \\
\text { (feet) }\end{array}$ & $\begin{array}{l}\text { Pier } \\
\text { scour } \\
\text { depth } \\
\text { (feet) }\end{array}$ & $\begin{array}{l}\text { Depth of } \\
\text { total scour } \\
\text { (feet) }\end{array}$ & $\begin{array}{c}\text { Elevation of } \\
\text { scour }^{2} \\
\text { (feet) }\end{array}$ & $\begin{array}{c}\text { Remaining } \\
\text { footing/pile } \\
\text { depth } \\
\text { (feet) }\end{array}$ \\
\hline \multicolumn{12}{|c|}{500 -yr. discharge is 5,750 cubic-feet per second } \\
\hline Left abutment & 0.0 & -- & 496.5 & -- & 483.5 & 3.2 & 11.0 & -- & 14.2 & 469.3 & -- \\
\hline Right abutment & 46.3 & -- & 496.4 & -- & 480.0 & 3.2 & 22.2 & -- & 25.4 & 454.6 & -- \\
\hline
\end{tabular}

1.Measured along the face of the most constricting side of the bridge.

2.Arbitrary datum for this study. 


\section{SELECTED REFERENCES}

Arcement, G.J., Jr., and Schneider, V.R., 1989, Guide for selecting Manning's roughness coefficients for natural channels and flood plains: U.S. Geological Survey Water-Supply Paper 2339, 38 p.

Barnes, H.H., Jr., 1967, Roughness characteristics of natural channels: U.S. Geological Survey Water-Supply Paper 1849,213 p.

Benson, M. A., 1962, Factors Influencing the Occurrence of Floods in a Humid Region of Diverse Terrain: U.S. Geological Survey WaterSupply Paper 1580-B, 64 p.

Brown, S.A. and Clyde, E.S., 1989, Design of riprap revetment: Federal Highway Administration Hydraulic Engineering Circular No. 11, Publication FHWA-IP-89-016, 156 p.

Federal Highway Administration, 1983, Runoff estimates for small watersheds and development of sound design: Federal Highway Administration Report FHWA-RD-77-158.

Federal Highway Administration, 1993, Stream Stability and Scour at Highway Bridges: Participant Workbook: Federal Highway Administration Report FHWA-HI-91-011.

Froehlich, D.C., 1989, Local scour at bridge abutments in Ports, M.A., ed., Hydraulic Engineering--Proceedings of the 1989 National Conference on Hydraulic Engineering: New York, American Society of Civil Engineers, p. 13-18.

Hayes, D.C.,1993, Site selection and collection of bridge-scour data in Delaware, Maryland, and Virginia: U.S. Geological Survey WaterResources Investigation Report 93-4017, 23 p.

Interagency Advisory Committee on Water Data, 1982, Guidelines for determining flood flow frequency: U.S. Geological Survey, Bulletin 17B of the Hydrology Subcommittee, 190 p.

Johnson, C.G. and Tasker, G.D.,1974, Progress report on flood magnitude and frequency of Vermont streams: U.S. Geological Survey OpenFile Report 74-130, 37 p.

Lagasse, P.F., Schall, J.D., Johnson, F., Richardson, E.V., Chang, F., 1995, Stream Stability at Highway Structures: Federal Highway Administration Hydraulic Engineering Circular No. 20, Publication FHWA-IP-90-014, 144 p.

Laursen, E.M., 1960, Scour at bridge crossings: Journal of the Hydraulics Division, American Society of Civil Engineers, v. 86, no. HY2, p. 39-53.

Potter, W. D., 1957a, Peak rates of runoff in the Adirondack, White Mountains, and Maine woods area, Bureau of Public Roads

Potter, W. D., 1957b, Peak rates of runoff in the New England Hill and Lowland area, Bureau of Public Roads

Richardson, E.V. and Davis, S.R., 1995, Evaluating scour at bridges: Federal Highway Administration Hydraulic Engineering Circular No. 18, Publication FHWA-IP-90-017, 204 p.

Richardson, E.V., Simons, D.B., and Julien, P.Y., 1990, Highways in the river environment: Federal Highway Administration Publication FHWA-HI-90-016.

Ritter, D.F., 1984, Process Geomorphology: W.C. Brown Co., Debuque, Iowa, 603 p.

Shearman, J.O., 1990, User's manual for WSPRO--a computer model for water surface profile computations: Federal Highway Administration Publication FHWA-IP-89-027, 187 p.

Shearman, J.O., Kirby, W.H., Schneider, V.R., and Flippo, H.N., 1986, Bridge waterways analysis model; research report: Federal Highway Administration Publication FHWA-RD-86-108, 112 p.

Talbot, A.N., 1887, The determination of water-way for bridges and culverts.

U.S. Department of Transportation, 1993, Stream stability and scour at highway bridges, Participant Workbook: Federal Highway Administration Publication FHWA HI-91-011.

U.S. Geological Survey, 1980, Bethel, Vermont 7.5 Minute Series quadrangle map: U.S. Geological Survey Topographic Maps, Scale $1: 24,000$. 


\section{APPENDIX A: \\ WSPRO INPUT FILE}




\section{WSPRO INPUT FILE}

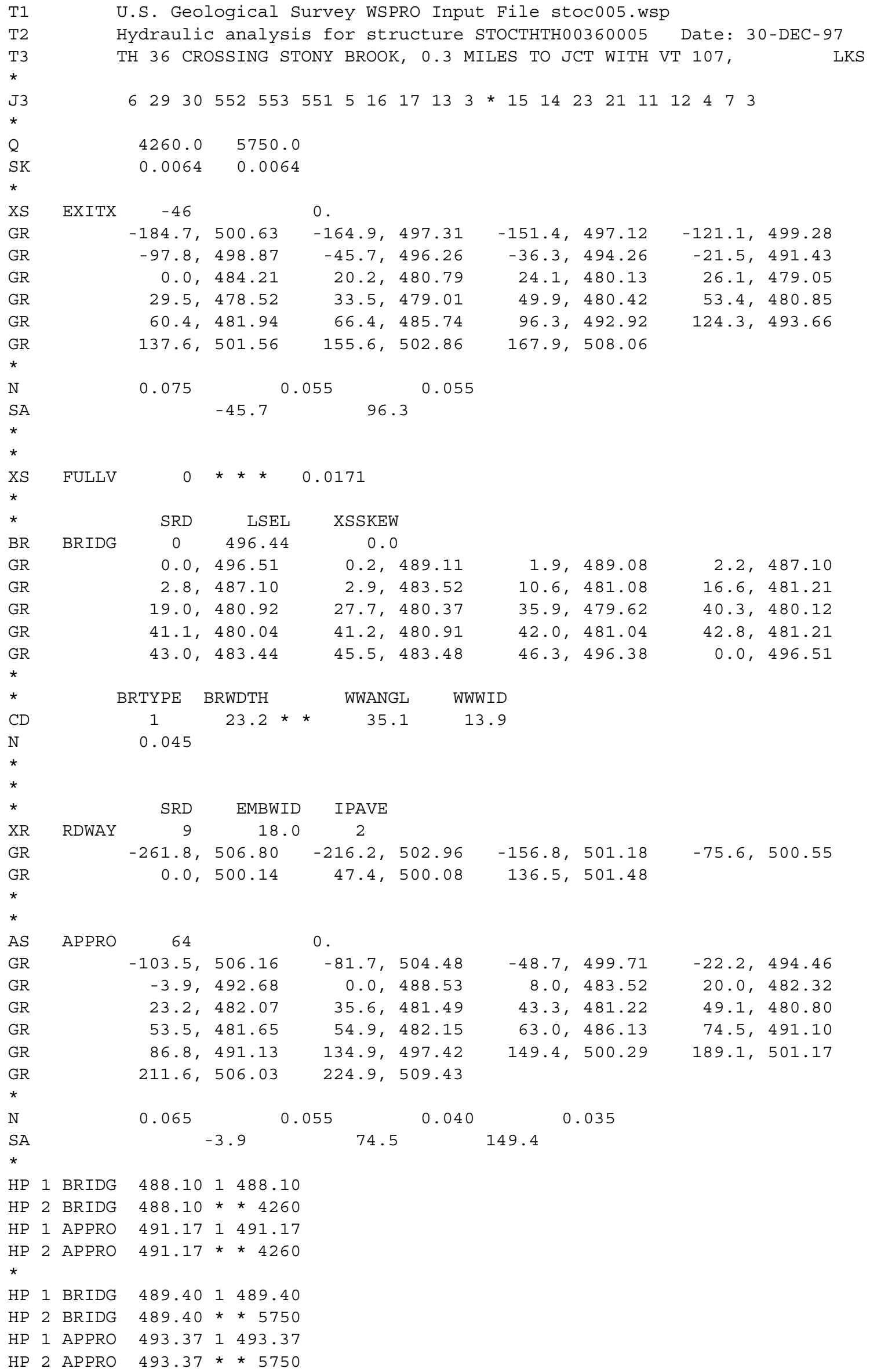




\section{APPENDIX B: \\ WSPRO OUTPUT FILE}


WSPRO OUTPUT FILE

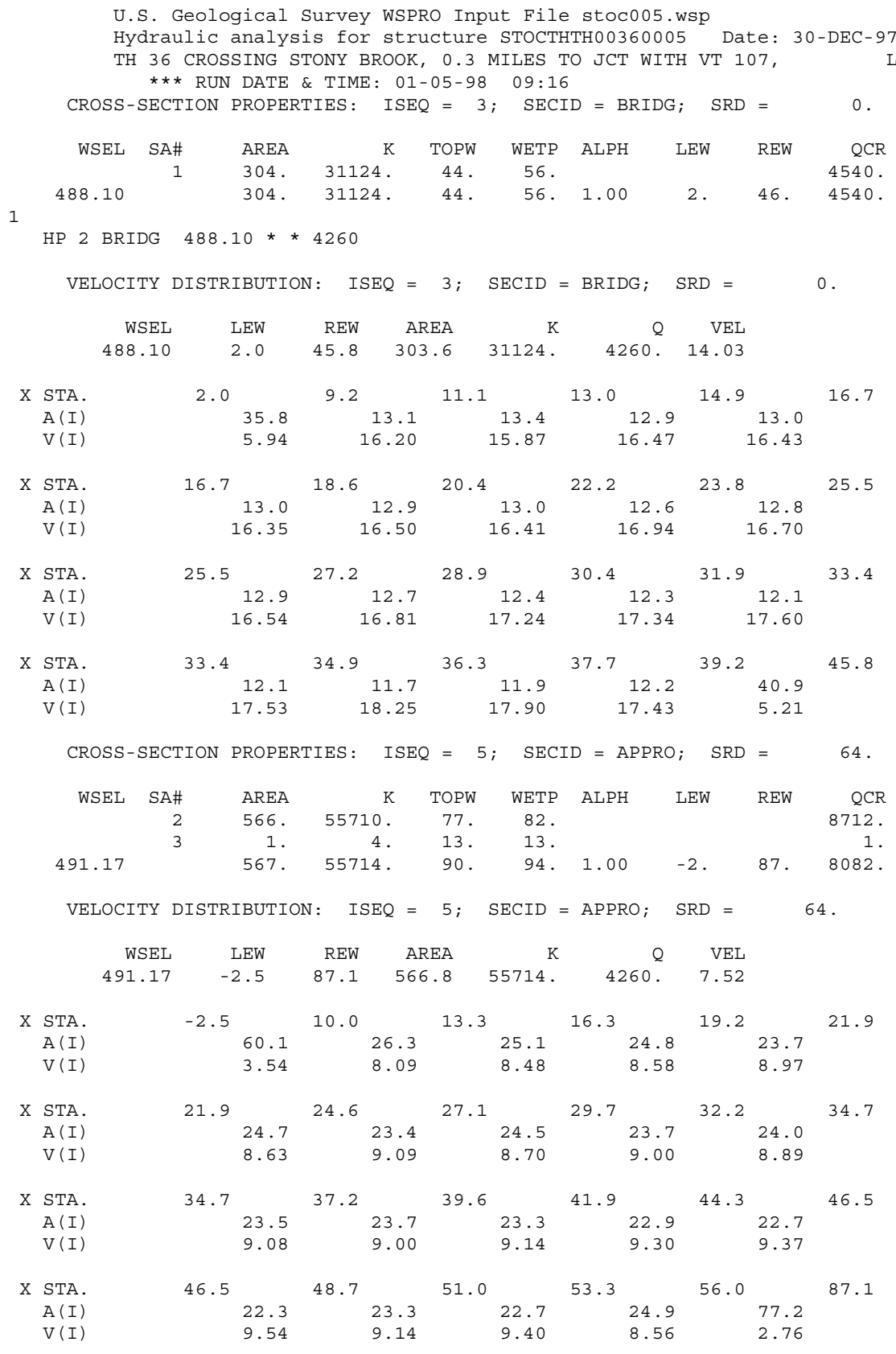


WSPRO OUTPUT FILE (continued)

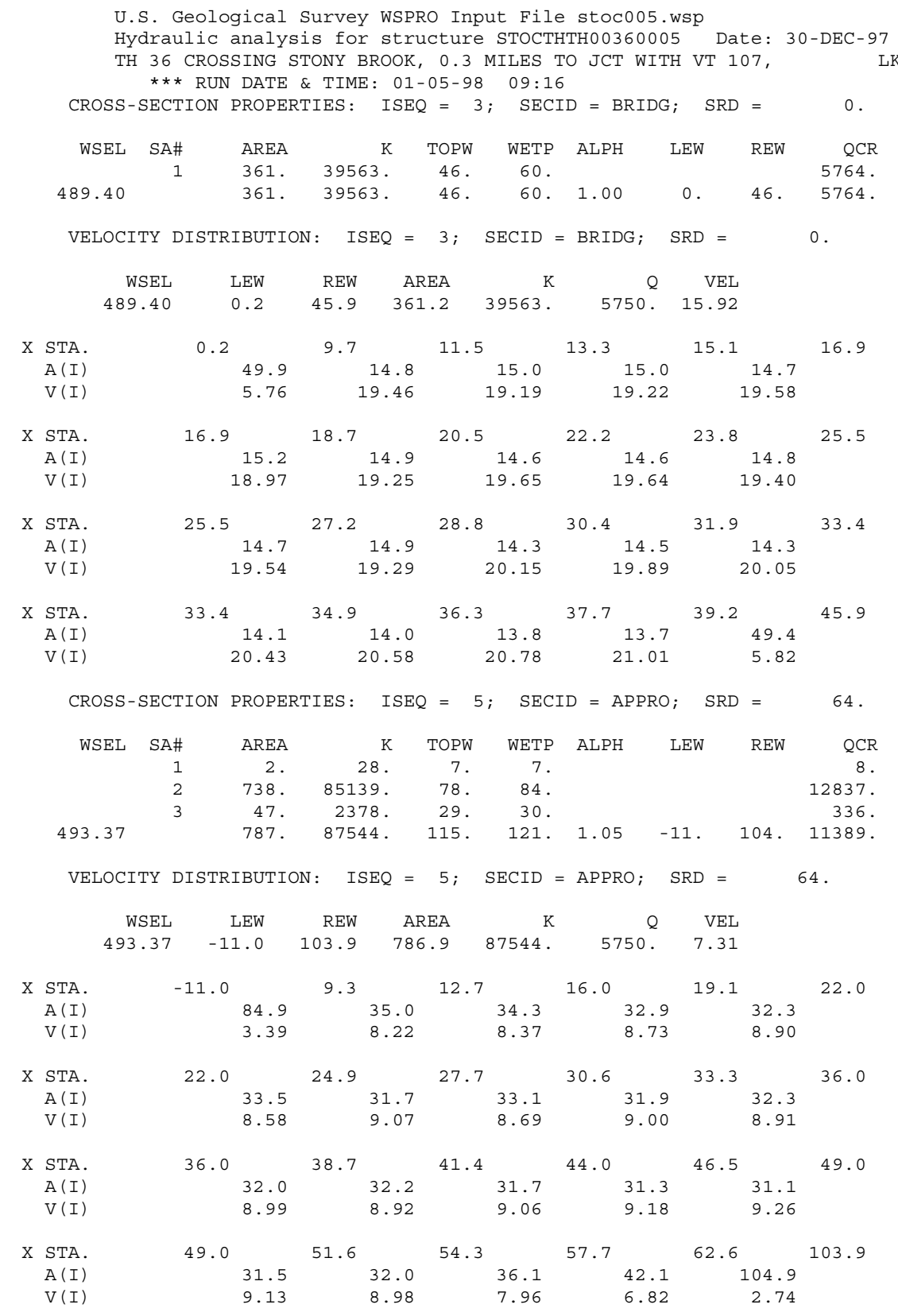


WSPRO OUTPUT FILE (continued)

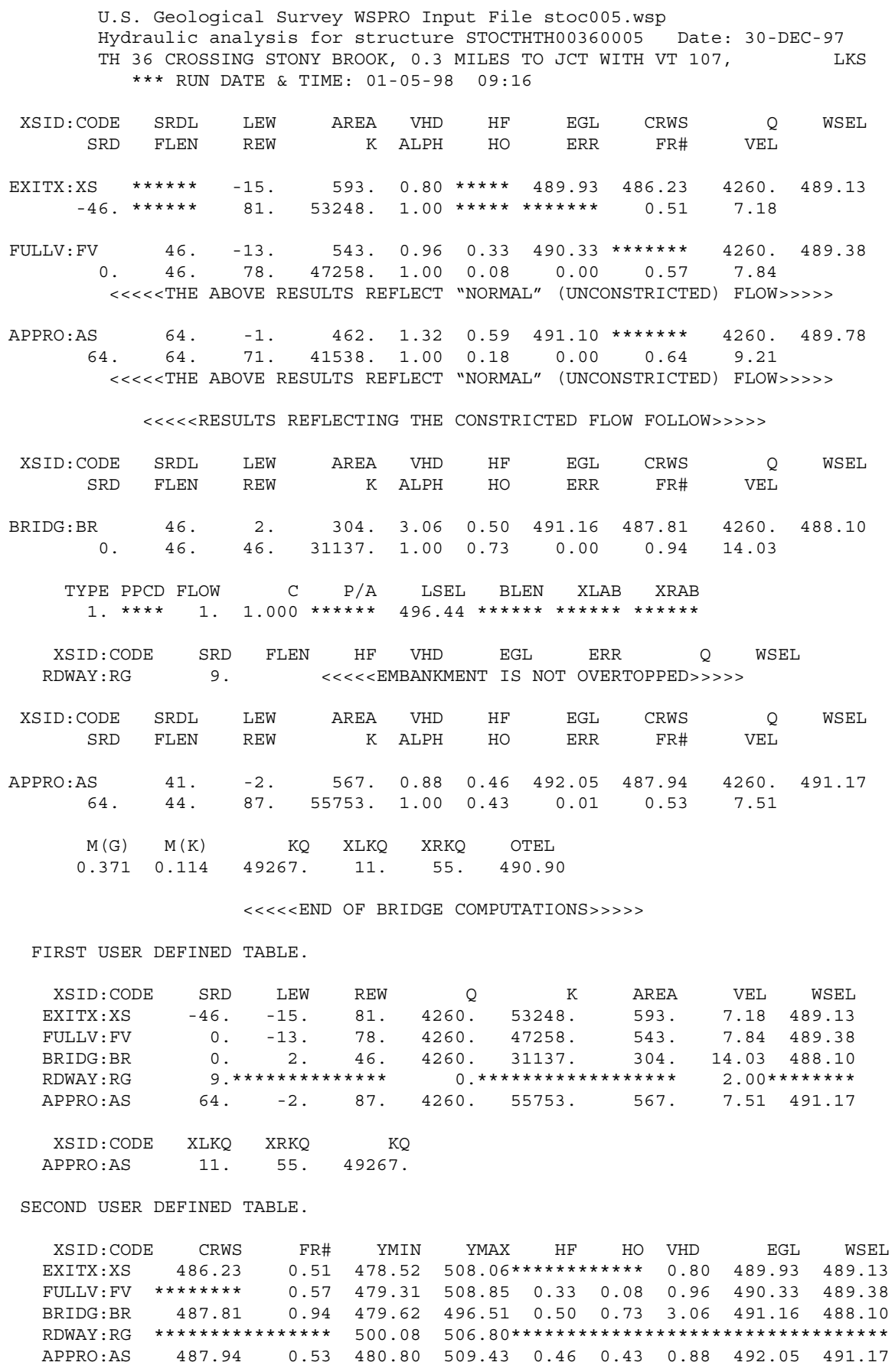


WSPRO OUTPUT FILE (continued)

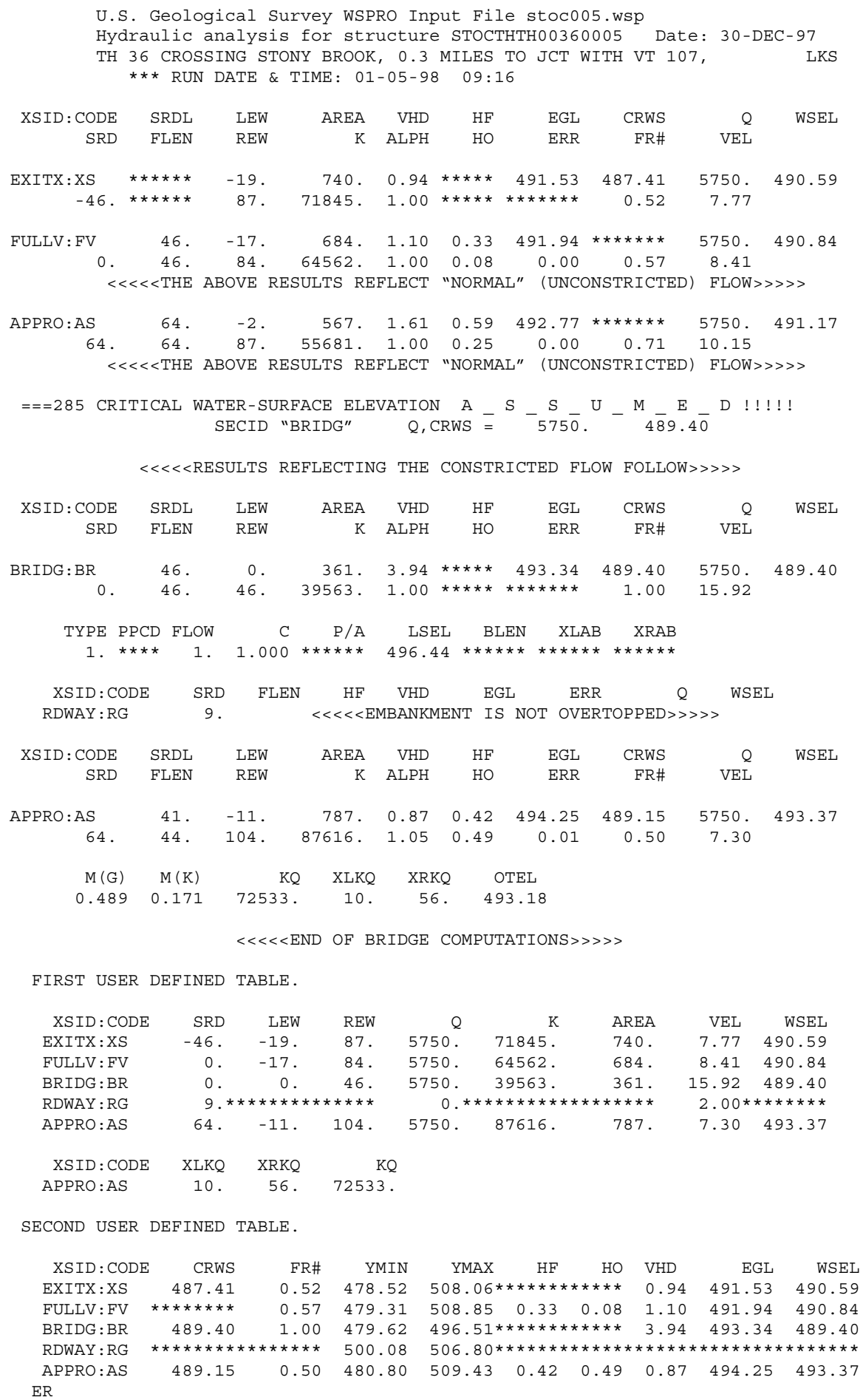




\section{APPENDIX C:}

\section{BED-MATERIAL PARTICLE-SIZE DISTRIBUTION}




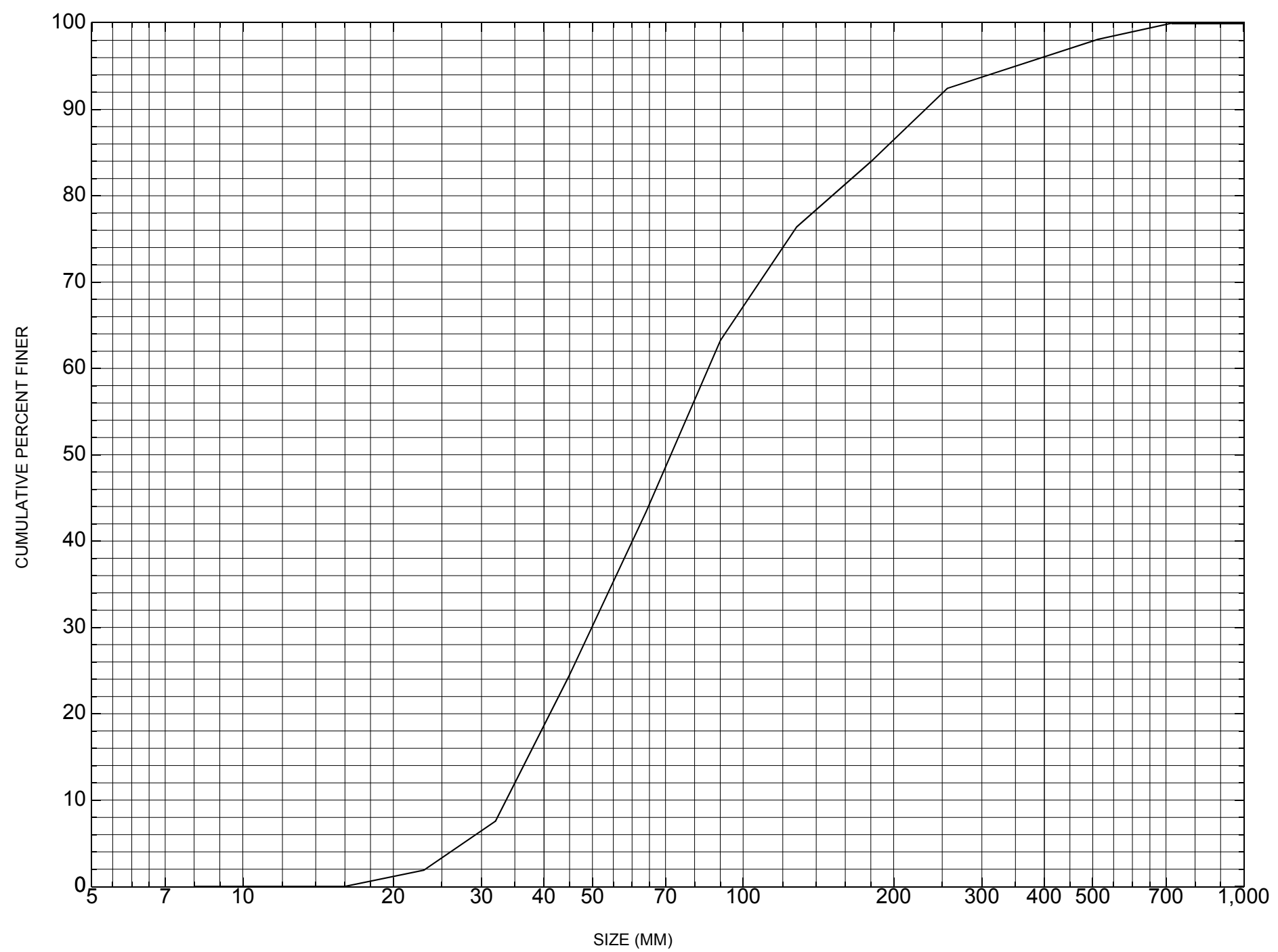

Appendix C. Bed material particle-size distribution for a pebble count in the channel approach of structure STOCTH00360005, in Stockbridge, Vermont. 


\section{APPENDIX D: \\ HISTORICAL DATA FORM}




\section{Structure Number STOCTH00360005}

\section{General Location Descriptive}

Data collected by (First Initial, Full last name) $\mathbf{E}$. BOEHMLER

Date $(M M / D D / Y Y) \_\mathbf{0 3} / \underline{23} / \underline{95}$

Highway District Number (I - 2; nn) $\mathbf{0 4}$

Town (FIPS place code; I - 4; nnnnn) $\mathbf{7 0 3 7 5}$

Waterway (I - 6) STONY BROOK

Route Number TH036

Topographic Map Bethel

Latitude (I - 16; nnnn.n) $\mathbf{4 3 4 5 7}$
County (FIPS county code; I - 3; nnn)

Mile marker (I - 11; nnn.nnn) $\mathbf{0 0 0 0 0 0}$

Road Name (I - 7): -

Vicinity (I - 9) 0.3 MI TO JCT W VT107

Hydrologic Unit Code: $\mathbf{0 1 0 8 0 1 0 5}$

Longitude (i - 17; nnnnn.n) $\mathbf{7 2 4 2 4}$

\section{Select Federal Inventory Codes}

FHWA Structure Number (I - 8) 10141900051419

Maintenance responsibility $(I-21 ; n n) \quad \mathbf{0 3}$

Year built (I - 27; YYYY) 1992

Average daily traffic, ADT (I - 29; nnnnnn) 000200

Year of ADT (I - 30; YY) $\mathbf{9 1}$

Opening skew to Roadway $(I-34 ; n n) \quad \mathbf{0 0}$

Operational status $(I-41 ; X) \underline{\mathbf{A}}$

Structure type (I- 43; nnn) $\mathbf{3 0 2}$

Approach span structure type (I - 44; nnn) $\mathbf{0 0 0}$

Number of spans (I - 45; nnn) $\mathbf{0 0 1}$

Number of approach spans (I - 46; nnnn) $\mathbf{0 0 0 0}$

Comments:

The structural inspection report of 7/14/94 indicates the structure is a single span, steel stringer type bridge with a concrete deck. The abutment walls and wingwalls are concrete and only have minor shrinkage cracks reported. The footings of both abutments are exposed with some undermining noted on the right abutment. The left abutment is doweled or sealed into bedrock, which outcrops at the base of the left abutment footing. The waterway is noted as proceeding straight through the crossing. The streambed consists of stone and gravel. The report mentions that some past undermining below the right abutment footing was corrected with some free poured concrete and steel railroad rails (Continued, page 31 ). 


\section{Bridge Hydrologic Data}

Is there hydrologic data available? $\underline{\mathbf{N}}$ if No, type ctrl-n $h \quad$ VTAOT Drainage area $\left(m i^{2}\right)$ : -

Terrain character:

Stream character \& type: -

Streambed material:

Discharge Data (cfs):

$$
\begin{aligned}
& Q_{2.33}- \\
& Q_{50}-
\end{aligned}
$$

Record flood date $(M M / D D / Y Y)$ :

Estimated Discharge (cfs): Ice conditions (Heavy, Moderate, Light) : -

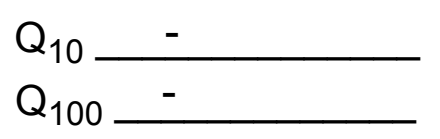

$$
\begin{aligned}
& Q_{25}- \\
& Q_{500}-
\end{aligned}
$$

Water surface elevation $(f t):-$

The stage increases to maximum highwater elevation (Rapidly, Not rapidly):

The stream response is (Flashy, Not flashy):

Describe any significant site conditions upstream or downstream that may influence the stream's stage: -

Watershed storage area (in percent): _ _ \%

The watershed storage area is: - (1-mainly at the headwaters; 2- uniformly distributed; 3-immediatly upstream oi the site)

Water Surface Elevation Estimates for Existing Structure:

\begin{tabular}{|l|l|l|l|l|l|}
\hline Peak discharge frequency & $Q_{2.33}$ & $Q_{10}$ & $Q_{25}$ & $Q_{50}$ & $Q_{100}$ \\
Water surface elevation (ft)) & - & - & - & - & - \\
Velocity (ft/sec) & - & - & - & - & - \\
\hline
\end{tabular}

Long term stream bed changes: -

Is the roadway overtopped below the $\mathrm{Q}_{100}$ ? (Yes, No, Unknown): $\mathbf{U}$ Frequency: Relief Elevation (ft): Discharge over roadway at $Q_{100}\left(f^{3} / \mathrm{sec}\right)$ :

Are there other structures nearby? (Yes, No, Unknown): $\underline{\mathbf{U}}$ Upstream distance (miles): Town: If No or Unknown, type ctrl-n os Highway No. : Structure No. : Year Built:

Clear span (ft): Clear Height $(f t)$ : Full Waterway $\left(f^{2}\right)$ : 
Downstream distance (miles): Town: Year Built:

Highway No. : Structure No. : Structure Type:

Clear span (ft): Clear Height $(f t)$ : Full Waterway $\left(f^{2}\right)$ :

Comments:

Some of the gravel below the downstream end of the free poured concrete has been eroded. Other than this, the report does not mention anything significant concerning channel scour, bank erosion, or debris accumulation at this bridge site.

\section{USGS Watershed Data}

Watershed Hydrographic Data

Drainage area (DA)

Watershed storage (ST)

Bridge site elevation

Main channel length 700 9.02 $10 \%$ channel length elevation $\mathrm{mi}^{2}$ 0 $\%$ th $\mathrm{mi}$

Main channel slope

(S) 140.43 750 $\mathrm{ft} \quad 85 \%$ channel length elevation 1700 $\mathrm{ft}$

Watershed Precipitation Data

Average site precipitation in Average headwater precipitation in

Maximum 2yr-24hr precipitation event $(124,2)$ in

Average seasonal snowfall (Sn) $\mathrm{ft}$ 


\section{Bridge Plan Data}

Are plans available? $\mathbf{N} \quad$ If no, type ctrl-n pl Date issued for construction (MM / YYYY):

Project Number

Minimum channel bed elevation:

Low superstructure elevation: USLAB DSLAB USRAB DSRAB Benchmark location description:

There is no benchmark information available.

Reference Point (MSL, Arbitrary, Other):

Datum (NAD27, NAD83, Other):

Foundation Type: 4

If 1: Footing Thickness

If 2: Pile Type:

If 3: Footing bottom elevation:

Is boring information available? $\mathbf{N}$

Foundation Material Type: $\mathbf{3}$

(1-Spreadfooting; 2-Pile; 3- Gravity; 4-Unknown)

Footing bottom elevation: -

Briefly describe material at foundation bottom elevation or around piles:

There is no foundation material information available.

Comments:

There are no bridge plans available. 


\section{Cross-sectional Data}

Is cross-sectional data available? $\mathbf{N}$ If no, type ctrl-n xs

Source (FEMA, VTAOT, Other)? -

Comments: There is no cross-section information available.

\begin{tabular}{|l|l|l|l|l|l|l|l|l|l|l|l|}
\hline Station & - & - & - & - & - & - & - & - & - & - & - \\
\hline Feature & - & - & - & - & - & - & - & - & - & - & - \\
\hline $\begin{array}{l}\text { Low chord } \\
\text { elevation }\end{array}$ & - & - & - & - & - & - & - & - & - & - & - \\
\hline $\begin{array}{l}\text { Bed } \\
\text { elevation }\end{array}$ & - & - & - & - & - & - & - & - & - & - & - \\
\hline $\begin{array}{l}\text { Low chord } \\
\text { to bed }\end{array}$ & - & - & - & - & - & - & - & - & - & - & - \\
\hline Station & - & - & - & - & - & - & - & - & - & - & - \\
\hline Feature & - & - & - & - & - & - & - & - & - & - & - \\
\hline $\begin{array}{l}\text { Low chord } \\
\text { elevation }\end{array}$ & - & - & - & - & - & - & - & - & - & - & - \\
\hline $\begin{array}{l}\text { Bed } \\
\text { elevation }\end{array}$ & - & - & - & - & - & - & - & - & - & - & - \\
\hline $\begin{array}{l}\text { Low chord } \\
\text { to bed }\end{array}$ & - & - & - & - & - & - & - & - & - & - & - \\
\hline
\end{tabular}

Source (FEMA, VTAOT, Other)?

Comments: There is no cross-section information available.

\begin{tabular}{|l|l|l|l|l|l|l|l|l|l|l|l|}
\hline Station & - & - & - & - & - & - & - & - & - & - & - \\
\hline Feature & - & - & - & - & - & - & - & - & - & - & - \\
\hline $\begin{array}{l}\text { Low chord } \\
\text { elevation }\end{array}$ & - & - & - & - & - & - & - & - & - & - & - \\
\hline $\begin{array}{l}\text { Bed } \\
\text { elevation }\end{array}$ & - & - & - & - & - & - & - & - & - & - & - \\
\hline $\begin{array}{l}\text { Low chord } \\
\text { to bed }\end{array}$ & - & - & - & - & - & - & - & - & - & - & - \\
\hline Station & - & - & - & - & - & - & - & - & - & - & - \\
\hline Feature & - & - & - & - & - & - & - & - & - & - & - \\
\hline $\begin{array}{l}\text { Low chord } \\
\text { elevation }\end{array}$ & - & - & - & - & - & - & - & - & - & - & - \\
\hline $\begin{array}{l}\text { Bed } \\
\text { elevation }\end{array}$ & - & - & - & - & - & - & - & - & - & - & - \\
\hline $\begin{array}{l}\text { Low chord } \\
\text { to bed }\end{array}$ & - & - & - & - & - & - & - & - & - & - & - \\
\hline
\end{tabular}




\section{APPENDIX E: \\ LEVEL I DATA FORM}


U. S. Geological Survey

Bridge Field Data Collection and Processing Form

Qa/Qc Check by: $\underline{\mathbf{R B}}$ Date: 10/04/96

\section{Structure Number STOCTH00360005}

\section{A. General Location Descriptive}

1. Data collected by (First Initial, Full last name) M. WEBER

2. Highway District Number 04

Date $(M M / D D / Y Y) \mathbf{0 4} / \underline{12} / \underline{1995}$

County Windsor (027)

Mile marker 00000

Waterway (I - 6) Stony Brook

Town Stockbridge (70375)

Route Number TH036

Road Name -

3. Descriptive comments:

Hydrologic Unit Code: $\mathbf{0 1 0 8 0 1 0 5}$

The bridge is located 0.3 miles from the junction with VT 107.

\section{B. Bridge Deck Observations}
4. Surface cover... LBUS 6
RBUS 4
LBDS 6
RBDS 6
Overall 6

(2b us,ds,lb,rb: 1- Urban; 2- Suburban; 3- Row crops; 4- Pasture; 5- Shrub- and brushland; 6- Forest; 7- Wetland)
5. Ambient water surface... US 2
UB 2
DS 1
(1- pool; 2- riffle)

6. Bridge structure type 1 (1- single span; 2- multiple span; 3- single arch; 4- multiple arch; 5-cylindrical culvert; 6- box culvert; or 7- other)
7. Bridge length $\mathbf{5 0}$
(feet)
Span length 48
(feet)
Bridge width 18 (feet)

\section{Road approach to bridge:}
8. LB 0
RB 2
( 0 even, 1- lower, 2- higher)
9. LB_2
RB $\underline{2}$
(1- Paved, 2- Not paved)

10. Embankment slope (run / rise in feet / foot)

US left

US right

\begin{tabular}{|c|c|c|c|}
\hline \multicolumn{2}{|c|}{ Protection } & \multirow{2}{*}{ 13.Erosion } & 14.Severity \\
\hline 11.Type & 12.Cond. & $\mathbf{0}$ & $\mathbf{0}$ \\
\hline $\mathbf{1}$ & $\mathbf{1}$ & $\mathbf{0}$ & $\mathbf{1}$ \\
\hline $\mathbf{2}$ & $\mathbf{1}$ & $\underline{\mathbf{2}}$ & $\mathbf{0}$ \\
\hline $\mathbf{3}$ & $\mathbf{1}$ & $\mathbf{0}$ & $\mathbf{0}$ \\
\hline $\mathbf{1}$ & $\mathbf{1}$ & $\mathbf{0}$ & $\underline{\mathbf{0}}$ \\
\hline
\end{tabular}

Bank protection types: 0- none; 1- < 12 inches;

2- < 36 inches; 3- < 48 inches;

4- < 60 inches; 5- wall / artificial levee

Bank protection conditions: 1- good; 2- slumped;

3- eroded; 4- failed

Erosion: 0 - none; 1- channel erosion; 2 -

road wash; 3- both; 4- other

Erosion Severity: 0 - none; 1- slight; 2- moderate; 3- severe

\section{Channel approach to bridge (BF):}

15. Angle of approach: $\mathbf{1 0}$

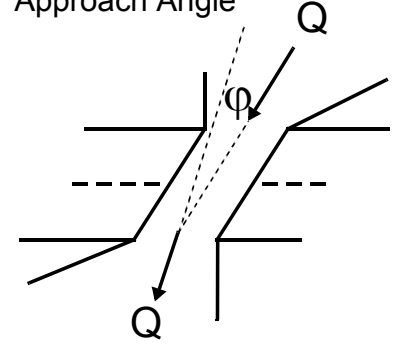

17. Channel impact zone 1:

Where? LB $(L B, R B)$

Range? 5 feet $\mathbf{U B}$

Channel impact zone 2:

Where? $(L B, R B)$

Range? - $\quad$ feet -

(US, UB, DS) to Impact Severity: 0- none to very slight; 1- Slight; 2- Moderate; 3- Severe feet -

16. Bridge skew: 5

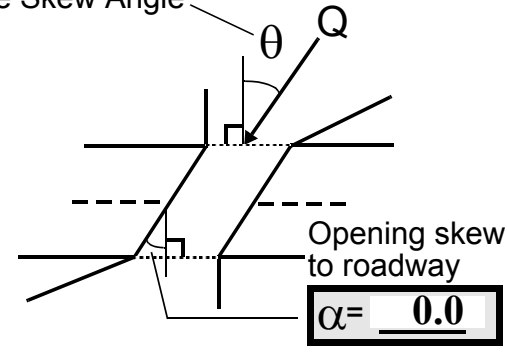

\section{Exist? $\mathbf{Y}(Y$ or $N)$}

Severity 1

, UB, DS) to $\mathbf{2 0}$ feet $\underline{\mathbf{D S}}$

Exist? $\mathbf{N}(Y$ or $N)$

Severity Bridge Skew Angle 
18. Bridge Type: $\underline{\mathbf{1 b} / \mathbf{1 a}}$

1a- Vertical abutments with wingwalls

1 b- Vertical abutments without wingwalls

2- Vertical abutments and wingwalls, sloping embankment Wingwalls parallel to abut. face

3- Spill through abutments

4- Sloping embankment, vertical wingwalls and abutments

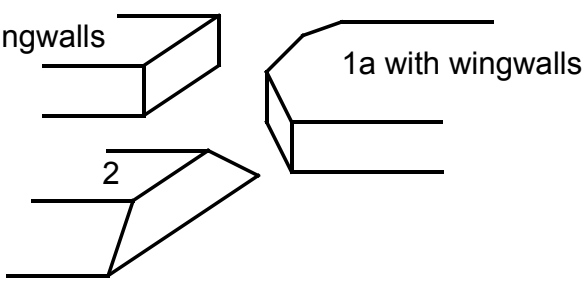

Wingwall angle less than $90^{\circ}$.

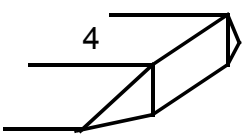

19. Bridge Deck Comments (surface cover variations, measured bridge and span lengths, bridge type variations, approach overflow width, etc.)

7. Bridge dimension values are from the VT AOT files. Measured bridge length is $59.5 \mathrm{ft}$, span length is 46.5

$\mathrm{ft}$, and the bridge width is $18 \mathrm{ft}$.

4. The US and DS left bank surface cover is forest. The forest is partially cleared. Along the DS left bank many of the trees are young. The DS right bank is also forested. There are two dirt roads within the 2 bridge lengths of the DS right bank. The US right bank is pasture with some shrubs and brush.

5. The DS water surface is pooled to about $75 \mathrm{ft} D S$ and is riffled further DS.

17. Impact zone 1 is a bedrock outcrop under the bridge. There is a severe channel bend to the left beginning about $100 \mathrm{ft}$ DS. There is a low area on the outside of the bend which will be submerged at high flows.

11. Road approach protection on the US left bank is type 1 and type 2 .

18. The level II bridge type is $1 \mathrm{~b}$ on the left abutment and $1 \mathrm{a}$ on the right abutment.

\section{Upstream Channel Assessment}

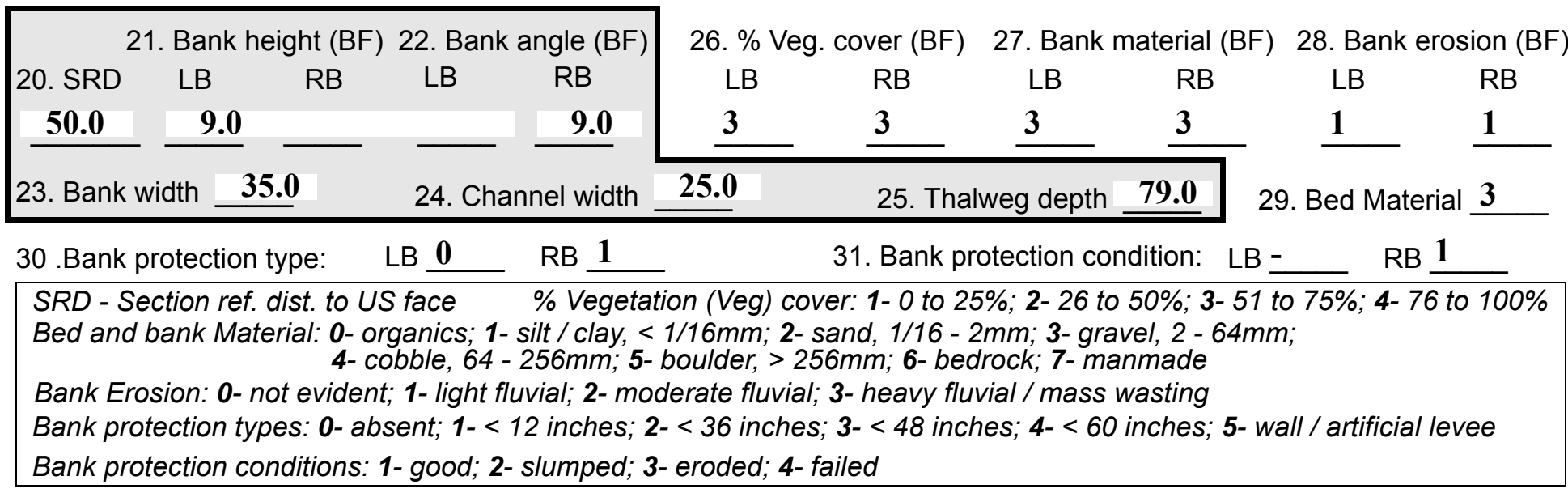

32. Comments (bank material variation, minor inflows, protection extent, etc.):

27. Bank material is gravel, sand, cobble and boulder.

28. Bed material is gravel, cobble, boulder and sand.

30. The right bank protection is mainly natural streambed material placed by man. Near the bridge are some larger boulders and blocks of concrete. The right bank protection goes from $0 \mathrm{ft}$ US to approximately $175 \mathrm{ft}$ US. On the left bank US there is natural protection from bedrock and boulders to $200 \mathrm{ft}$ US, then there is a gravel side bar. There is a large bedrock exposure at $225 \mathrm{ft}$ US where the channel makes a severe right turn. 
36. Point bar extent: 20 feet US

(US, UB) to 200 feet $\underline{\mathbf{U S}}$

(US, UB, DS) positioned $\underline{\mathbf{0}}$ $\%$ LB to 40 $\% R B$

37. Material: $\mathbf{3}$

38. Point or side bar comments (Circle Point or Side; Note additional bars, material variation, status, etc.):

The bar material is gravel, sand, and cobble with boulders and bedrock at the US end. There is some brushy vegetation on the bar.

39. Is a cut-bank present? $\mathbf{N}$ ( $Y$ or if $N$ type ctrl-n $c b)$ 40. Where? - $(L B$ or $R B)$

41. Mid-bank distance: -

42. Cut bank extent: feet (US, UB) to feet (US, UB, DS)

43. Bank damage: (1- eroded and/or creep; 2- slip failure; 3- block failure)

44. Cut bank comments (eg. additional cut banks, protection condition, etc.):

There are no cut-banks upstream at this site.

\section{Is channel scour present? $\mathbf{N}$ ( $Y$ or if $N$ type ctrl-n cs)}

47. Scour dimensions: Length Width Depth : 46. Mid-scour distance: -

48. Scour comments (eg. additional scour areas, local scouring process, etc.):

There is some channel scour $250 \mathrm{ft}$ US at the base of the bedrock outcrop.

\section{Are there major confluences? $\mathbf{N}$}

51. Confluence 1: Distance Confluence 2: Distance 52. Enters on Enters on 54. Confluence comments (eg. confluence name):

There are no major confluences upstream at this site.
50. How many? -

53. Type(1- perennial; 2- ephemeral)

Type (1-perennial; 2- ephemeral)

\section{Under Bridge Channel Assessment}

55. Channel restraint (BF)? LB 2

\begin{tabular}{|ccccc}
\hline \multicolumn{2}{|c}{ 56. Height (BF) } & \multicolumn{3}{c}{57 Angle (BF) } \\
LB & RB & LB & RB \\
47.0 & & & $\mathbf{1 . 5}$ & \\
\hline
\end{tabular}

58. Bank width (BF) (1- natural bank; 2- abutment; 3- artificial levee)

Bed and bank Material: 0- organics; 1- silt / clay, < 1/16mm; 2- sand, 1/16 - 2mm; 3- gravel, 2 - 64mm; 4- cobble, 64 - 256mm; 5- boulder, > 256mm; 6- bedrock; 7- manmade

61. Material (BF) 62. Erosion (BF)

LB RB LB RB

$\underline{2} \quad \underline{7} \quad \underline{-}$

60. Thalweg depth $\mathbf{9 0 . 0}$

63. Bed Material -

Bank Erosion: 0- not evident; 1- light fluvial; 2- moderate fluvial; 3- heavy fluvial / mass wasting

64. Comments (bank material variation, minor inflows, protection extent, etc.):

3

63. The bed material is gravel, cobble, and boulder with bedrock exposed on the left side of the channel. 
65. Debris and Ice Is there debris accumulation? $(Y$ or $N)$ 66. Where? $\mathbf{N}$ (1- Upstream; 2- At bridge; 3- Both)

67. Debris Potential ( 1- Low; 2- Moderate; 3- High)

69. Is there evidence of ice build-up? 1 (Y or N)

68. Capture Efficiency 2 (1-Low; 2- Moderate; 3- High)

70. Debris and Ice Comments:

Ice Blockage Potential $\mathbf{N}$ (1-Low; 2- Moderate; 3- High) 1

The debris potential is moderate since the reach beyond $200 \mathrm{ft}$ US is laterally unstable. Capture efficiency is low since the bridge will barely constrict bank full flow.

\begin{tabular}{|l|c|c|c|c|c|c|c|c|}
\hline Abutments & $\begin{array}{c}71 . \text { Attack } \\
\angle \text { (BF) }\end{array}$ & $\begin{array}{c}72 \text {. Slope } \angle \\
\text { (Qmax) }\end{array}$ & $\begin{array}{c}\text { 73. Toe } \\
\text { loc. (BF) }\end{array}$ & $\begin{array}{c}\text { 74. Scour } \\
\text { Condition }\end{array}$ & $\begin{array}{c}75 . \text { Scour } \\
\text { depth }\end{array}$ & $\begin{array}{c}\text { 76. Exposure } \\
\text { depth }\end{array}$ & 77. Material & 78. Length \\
\hline LABUT & & - & $\mathbf{9 0}$ & $\mathbf{0}$ & $\mathbf{2}$ & $\mathbf{0}$ & $\mathbf{6}$ & $\mathbf{9 0 . 0}$ \\
\hline RABUT & $\mathbf{1}$ & - & $\mathbf{9 0}$ & & & $\mathbf{2}$ & $\mathbf{3}$ & $\mathbf{4 5 . 5}$ \\
\hline
\end{tabular}

Pushed: $L B$ or RB

Toe Location (Loc.): 0- even, 1- set back, 2- protrudes

Scour cond.: 0- not evident; 1- evident (comment); 2- footing exposed; 3-undermined footing; 4- piling exposed; 5- settled; 6- failed

Materials: 1- Concrete; 2- Stone masonry or drywall; 3- steel or metal; 4- wood

79. Abutment comments (eg. undermined penetration, unusual scour processes, debris, etc.):

$\mathbf{0}$

3

1

The left abutment footing was poured directly on the exposed bedrock. The left abutment footing is actually two footings, the bottom footing is $4 \mathrm{ft}$ high on top of the bedrock then set back $1 \mathrm{ft}$ on top of this footing is another $2 \mathrm{ft}$ high footing. The right abutment footing is exposed along its entire length. The footing is $2 \mathrm{ft}$ thick. Below the right footing is a free poured subfooting of concrete and railroad track which is also exposed up to an additional $1 \mathrm{ft}$. Maximum exposure is at the DS end of the right abutment where it is also undermined by a maximum penetration of $3 \mathrm{ft}$. Vertical undermined distance is minimal, thus $1 \mathrm{ft}$ is the subfooting thickness. During high flows, the water forms an eddy upon exiting the channel under the bridge along the

80. Wingwalls:

Exist? Material? Scour Scour Exposure Angle? Length? Condition? depth? depth?

USLWW: right

abut

USRWW: .

DSLWW: $\mathbf{N}$

DSRWW: -

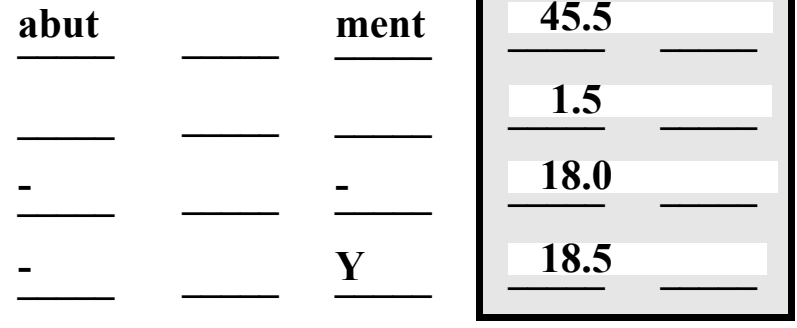

Wingwall materials: 1- Concrete; 2- Stone masonry or drywall; 3- steel or metal; 4- wood

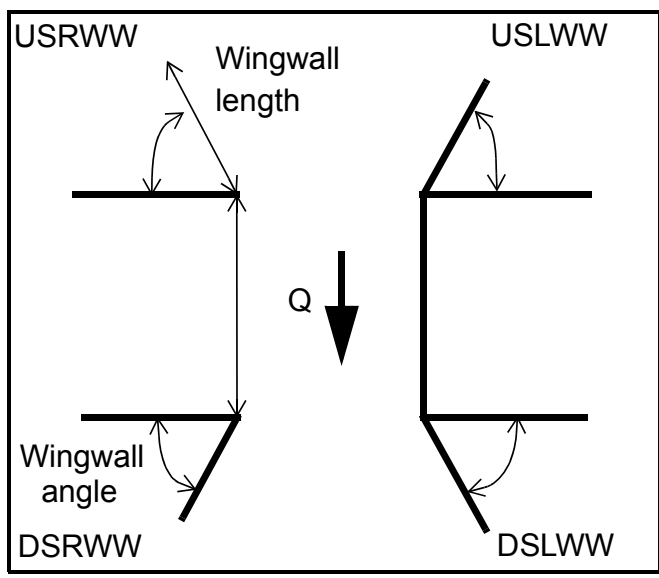

82. Bank / Bridge Protection:

\begin{tabular}{|l|l|l|l|l|l|l|l|c|}
\hline Location & USLWW & USRWW & LABUT & RABUT & LB & RB & DSLWW & DSRWW \\
\hline Type & $\mathbf{1}$ & $\mathbf{2}$ & - & $\mathbf{Y}$ & $\mathbf{0}$ & - & $\mathbf{1}$ & $\mathbf{1}$ \\
\hline Condition & $\mathbf{2}$ & $\mathbf{N}$ & - & $\mathbf{1}$ & $\mathbf{3}$ & - & $\mathbf{2}$ & $\mathbf{4}$ \\
\hline Extent & $\mathbf{0}$ & - & - & $\mathbf{3}$ & - & $\mathbf{2}$ & $\mathbf{1}$ & $\mathbf{0}$ \\
\hline
\end{tabular}

Bank / Bridge protection types: 0- absent; 1- < 12 inches; 2- < 36 inches; 3- < 48 inches; 4- < 60 inches; 
83. Wingwall and protection comments (eg. undermined penetration, unusual scour processes, etc.):

-
-
-
-
-
-
-
-
-
-

\section{Piers:}

84. Are there piers? $\mathbf{3}$ (Y or if $N$ type ctrl-n pr)

\begin{tabular}{|l|l|l|l|l|l|l|l|}
\hline \multirow{2}{*}{$\begin{array}{l}85 . \\
\text { Pier no. }\end{array}$} & \multicolumn{3}{|c|}{ width (w) feet } & \multicolumn{3}{c|}{ elevation (e) feet } \\
\cline { 2 - 8 } & w1 & w2 & w3 & e@w1 & e@w2 & e@w3 \\
\hline Pier 1 & - & & & - & $\mathbf{3 5 . 0}$ & $\mathbf{1 7 . 0}$ \\
\hline Pier 2 & - & & & - & $\mathbf{4 5 . 0}$ & $\mathbf{1 6 . 5}$ \\
\hline Pier 3 & - & - & - & - & - & - \\
\hline Pier 4 & - & - & - & - & - & - \\
\hline
\end{tabular}

\begin{tabular}{|l|l|l|l|l|}
\hline Level 1 Pier Descr. & \multicolumn{1}{|c|}{1} & \multicolumn{1}{|c|}{2} & \multicolumn{1}{|c|}{3} & \multicolumn{1}{|c|}{4} \\
\hline 86. Location (BF) & $\mathbf{1}$ & wall, 2 & sub- & ment. \\
\hline 87. Type & $\mathbf{3}$ & ft of & foot- & At \\
\hline 88. Material & $\mathbf{8 0 .}$ & the & ing is & the \\
\hline 89. Shape & At & foot- & visi- & junc- \\
\hline 90. Inclined? & the & ing is & ble & tion \\
\hline 91. Attack $\angle$ (BF) & DS & expo & at & of \\
\hline 92. Pushed & end & sed & the & the \\
\hline 93. Length (feet) & - & - & - & - \\
\hline 94. \# of piles & of & and & junc- & DS \\
\hline 95. Cross-members & the & the & tion & right \\
\hline 96. Scour Condition & US & free & with & wing \\
\hline 97. Scour depth & right & pour & the & wall \\
\hline 98. Exposure depth & wing & ed & abut & and \\
\hline
\end{tabular}

LFP, LTB, LB, MCL, MCM, MCR, RB, RTB, RFP

1- Solid pier, 2-column, 3- bent

1-Wood; 2- concrete; 3- metal; 4- stone

1- Round; 2- Square; 3- Pointed

Y-yes; $N$ - no

$L B$ or $R B$

0- none; 1- laterals; 2- diagonals; 3- both

0- not evident; 1- evident (comment);

2- footing exposed; 3- piling exposed;

4- undermined footing; 5- settled; 6- failed 
99. Pier comments (eg. undermined penetration, protection and protection extent, unusual scour processes, etc.):

the right abutment, $3 \mathrm{ft}$ of the footing is exposed, $1 \mathrm{ft}$ of which is the free poured subfooting which is also undermined with a maximum of $3 \mathrm{ft}$ penetration. The vertical extent of the undermining is minimal.

82. The US and DS ends of the left abutment are protected with type 1 and type 2 rip rap and its base length is set on bedrock. Some type 3 protection is at the extreme DS end of the DS right wingwall.

$\mathbf{N}$

100.

\section{E. Downstream Channel Assessment}

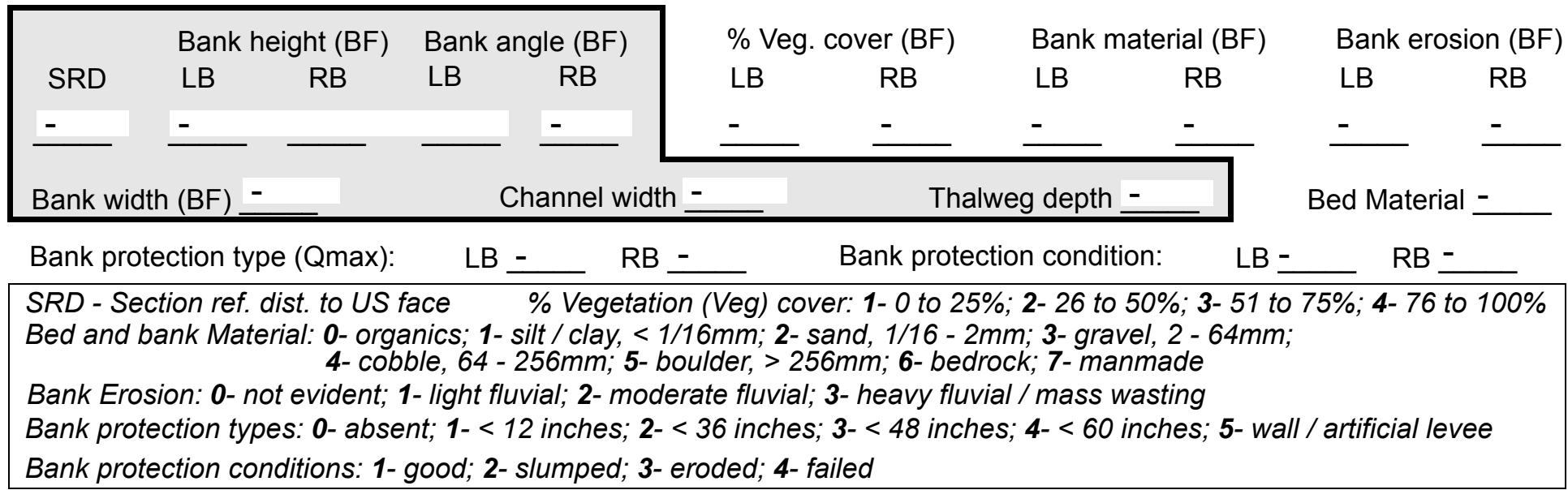

Comments (eg. bank material variation, minor inflows, protection extent, etc.):

$-$

$-$

$-$

$-$

$-$

$-$

$-$

$-$

$-$

$-$

101. Is a drop structure present? _ ( $Y$ or $N$, if $N$ type ctrl-n ds) 102. Distance: ___ feet
103. Drop: - feet
104. Structure material: -
(1- steel sheet pile; 2- wood pile; 3- concrete; 4- other)

105. Drop structure comments (eg. downstream scour depth): 
106. Point/Side bar present? (Y or $N$. if $N$ type ctrl-n pb)Mid-bar distance:

Mid-bar width: -

Point bar extent: feet -

(US, UB, DS) to feet (US, UB, DS) positioned $\%$ LB to $\%$ RB Material:

Point or side bar comments (Circle Point or Side; note additional bars, material variation, status, etc.):

S a cut-bank present? Th (Y or if $N$ type ctrl- $n c b) \quad$ Where? ere (LB or RB) Mid-bank distance: are Cut bank extent: no feet pie (US, UB, DS) to rs. feet (US, UB, DS)

Bank damage: (1- eroded and/or creep; 2- slip failure; 3- block failure)

Cut bank comments (eg. additional cut banks, protection condition, etc.):

Is channel scour present? ( $Y$ or if $N$ type ctrl-n cs)

Mid-scour distance:

Scour dimensions: Length Width 3 Depth: 3

Positioned $\mathbf{3}$ $\%$ LB to $\underline{\mathbf{3}} \%$ RB Scour comments (eg. additional scour areas, local scouring process, etc.): 3 1 3 $\mathbf{0}$

Are there major confluences? $\mathbf{0}$ ( $Y$ or if $N$ type ctrl-n $m c)$ Confluence 1: Distance Confluence 2: Distance $\mathbf{t}$ and Enters on The ( $L B$ or $R B$ ) Enters on left (LB or RB)
How many? -

Type righ (1-perennial; 2- ephemeral)

Type ban (1- perennial; 2- ephemeral)

Confluence comments (eg. confluence name):

$\mathrm{k}$ material is gravel, sand, cobble and boulder. Some areas on the left bank have exposed bedrock. The bed material is gravel, cobble, boulder, and sand with some bedrock exposures. Some natural boulder protection

\section{F. Geomorphic Channel Assessment}

107. Stage of reach evolution is

1- Constructed

2- Stable

3- Aggraded

4- Degraded

5- Laterally unstable

6- Vertically and laterally unstable 
108. Evolution comments (Channel evolution not considering bridge effects; See HEC-20, Figure 1 for geomorphic descriptors):

on the right bank DS. The left bank heavy fluvial erosion begins at $100 \mathrm{ft}$ DS. 


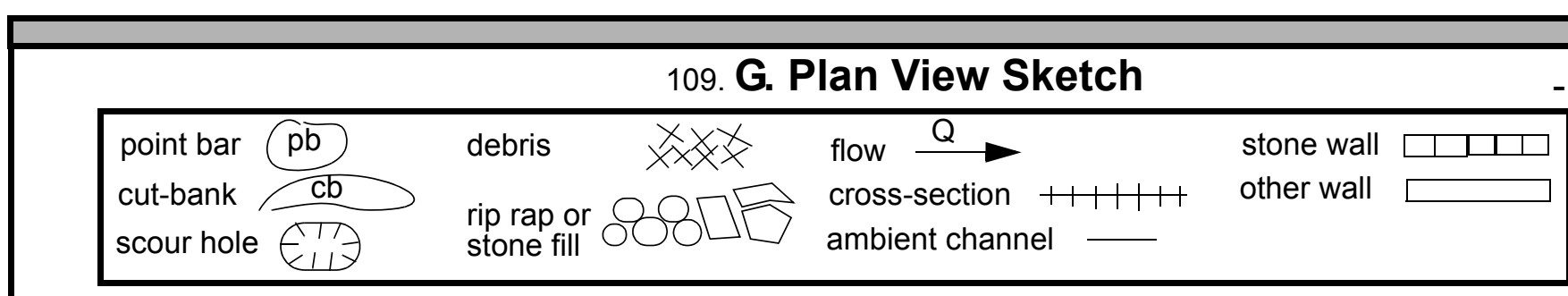


APPENDIX F:

SCOUR COMPUTATIONS 
SCOUR COMPUTATIONS

\begin{tabular}{|c|c|c|c|}
\hline Structure Number: STOCTH00360005 & & Town: & STOCKBRIDGE \\
\hline Road Number: $\quad$ TH 36 & & County: & WINDSOR \\
\hline STONY BROOK & & & \\
\hline Initials LKS & Checked: & RLB & \\
\hline Analysis of contraction scour, live & bed or $\mathrm{c}$ & lear wat & \\
\hline $\begin{array}{l}\text { Critical Velocity of Bed Material } \\
\text { VC=11.21*y1^0.1667*D50^0.33 with Ss } \\
\text { (Richardson and Davis, 1995, p. 28, }\end{array}$ & $\begin{array}{l}\text { converted } \\
=2.65 \\
\text { eq. } 16)\end{array}$ & to Engl & sh units) \\
\hline Approach Section & & & \\
\hline Characteristic & $100 \mathrm{yr}$ & $500 \mathrm{yr}$ & other $Q$ \\
\hline Total discharge, cfs & 4260 & 5750 & 0 \\
\hline Main Channel Area, ft2 & 566 & 736 & 0 \\
\hline Left overbank area, ft2 & 0 & 4 & 0 \\
\hline Right overbank area, ft2 & 1 & 47 & 0 \\
\hline Top width main channel, ft & 77 & 77 & 0 \\
\hline Top width L overbank, ft & 0 & 8 & 0 \\
\hline Top width $\mathrm{R}$ overbank, ft & 13 & 29 & 0 \\
\hline D50 of channel, ft & 0.2352 & 0.2352 & 0.2352 \\
\hline D50 left overbank, ft & -- & -- & -- \\
\hline D50 right overbank, ft & -- & -- & -- \\
\hline $\mathrm{Y}_{1}$, average depth, $\mathrm{MC}$, ft & 7.4 & 9.6 & ERR \\
\hline Y1, average depth, LOB, ft & ERR & 0.5 & ERR \\
\hline $\mathrm{Y}^{1}$, average depth, $\mathrm{ROB}$, ft & 0.1 & 1.6 & ERR \\
\hline Total conveyance, approach & 55714 & 88329 & 0 \\
\hline Conveyance, main channel & 55710 & 85904 & 0 \\
\hline Conveyance, LOB & 0 & 48 & 0 \\
\hline Conveyance, ROB & 4 & 2378 & 0 \\
\hline Percent discrepancy, conveyance & 0.0000 & -0.0011 & ERR \\
\hline Qm, discharge, MC, cfs & 4259.7 & 5592.1 & ERR \\
\hline Ql, discharge, LOB, Cfs & 0.0 & 3.1 & ERR \\
\hline Qr, discharge, ROB, Cfs & 0.3 & 154.8 & $\mathrm{ERR}$ \\
\hline $\mathrm{Vm}$, mean velocity $\mathrm{MC}$, ft/s & 7.5 & 7.6 & ERR \\
\hline VI, mean velocity, LOB, ft/s & ERR & 0.8 & ERR \\
\hline Vr, mean velocity, ROB, ft/s & 0.3 & 3.3 & ERR \\
\hline Vc-m, crit. velocity, MC, ft/s & 9.6 & 10.1 & $\mathrm{~N} / \mathrm{A}$ \\
\hline Vc-l, crit. velocity, LOB, ft/s & ERR & ERR & ERR \\
\hline Vc-r, crit. velocity, ROB, ft/s & ERR & ERR & ERR \\
\hline Results & & & \\
\hline Live-bed(1) or Clear-Water(0) Contr & action $\mathrm{Sc}$ & our? & \\
\hline Main Channel & 0 & 0 & $\mathrm{~N} / \mathrm{A}$ \\
\hline Left Overbank & $\mathrm{N} / \mathrm{A}$ & $\mathrm{N} / \mathrm{A}$ & $\mathrm{N} / \mathrm{A}$ \\
\hline Right Overbank & $\mathrm{N} / \mathrm{A}$ & $\mathrm{N} / \mathrm{A}$ & $\mathrm{N} / \mathrm{A}$ \\
\hline
\end{tabular}


Clear water Contraction Scour in MAIN CHANNEL

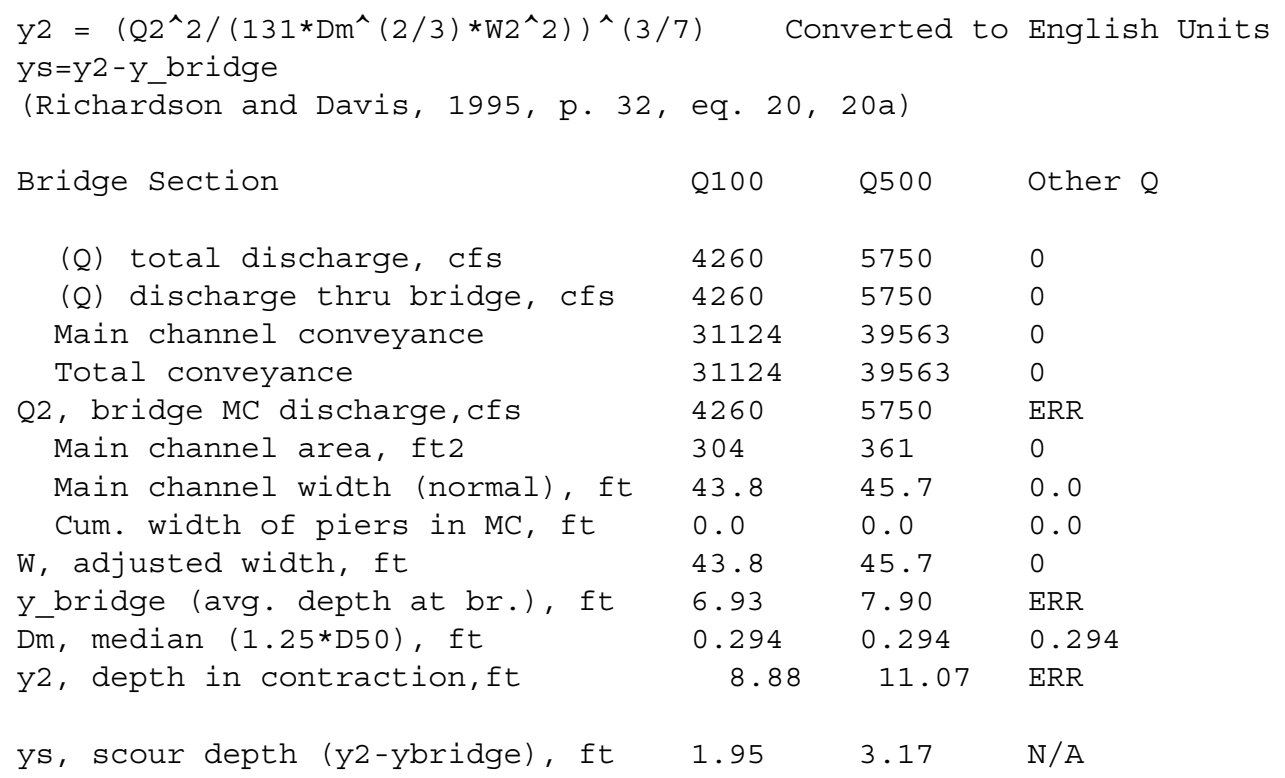

\begin{tabular}{|c|c|c|c|}
\hline \multicolumn{4}{|c|}{$\begin{array}{l}\text { Armoring } \\
\mathrm{DC}=\left[\left(1.94 * \mathrm{~V}^{\wedge} 2\right) /(5.75 * \log (12.27 * \mathrm{y} / \mathrm{D} 90)) \wedge 2\right] /[0.03 *(165-62.4)] \\
\text { Depth to Armoring }=3 *(1 / \mathrm{PC}-1)\end{array}$} \\
\hline Downstream bridge face property & $100-y r$ & $500-y r$ & Other $Q$ \\
\hline Q, discharge thru bridge $\mathrm{MC}$, cfs & 4260 & 5750 & $\mathrm{~N} / \mathrm{A}$ \\
\hline Main channel area (DS), ft2 & 303.6 & 361.2 & 0 \\
\hline Main channel width (normal), ft & 43.8 & 45.7 & 0.0 \\
\hline Cum. width of piers, ft & 0.0 & 0.0 & 0.0 \\
\hline Adj. main channel width, ft & 43.8 & 45.7 & 0.0 \\
\hline D90, ft & 0.7586 & 0.7586 & 0.0000 \\
\hline D95, ft & 1.1415 & 1.1415 & 0.0000 \\
\hline Dc, critical grain size, ft & 0.8934 & 1.0885 & ERR \\
\hline PC, Decimal percent coarser than DC & 0.070 & 0.054 & 0.000 \\
\hline armoring, ft & 35.45 & 57.32 & ERR \\
\hline
\end{tabular}


Abutment Scour

Froehlich's Abutment Scour

$\mathrm{Ys} / \mathrm{Y} 1=2.27 * \mathrm{~K} 1 * \mathrm{~K} 2 *\left(\mathrm{a}^{\prime} / \mathrm{Y} 1\right) \wedge 0.43 * \mathrm{Fr} 1{ }^{\wedge} 0.61+1$

(Richardson and Davis, 1995, p. 48, eq. 28)

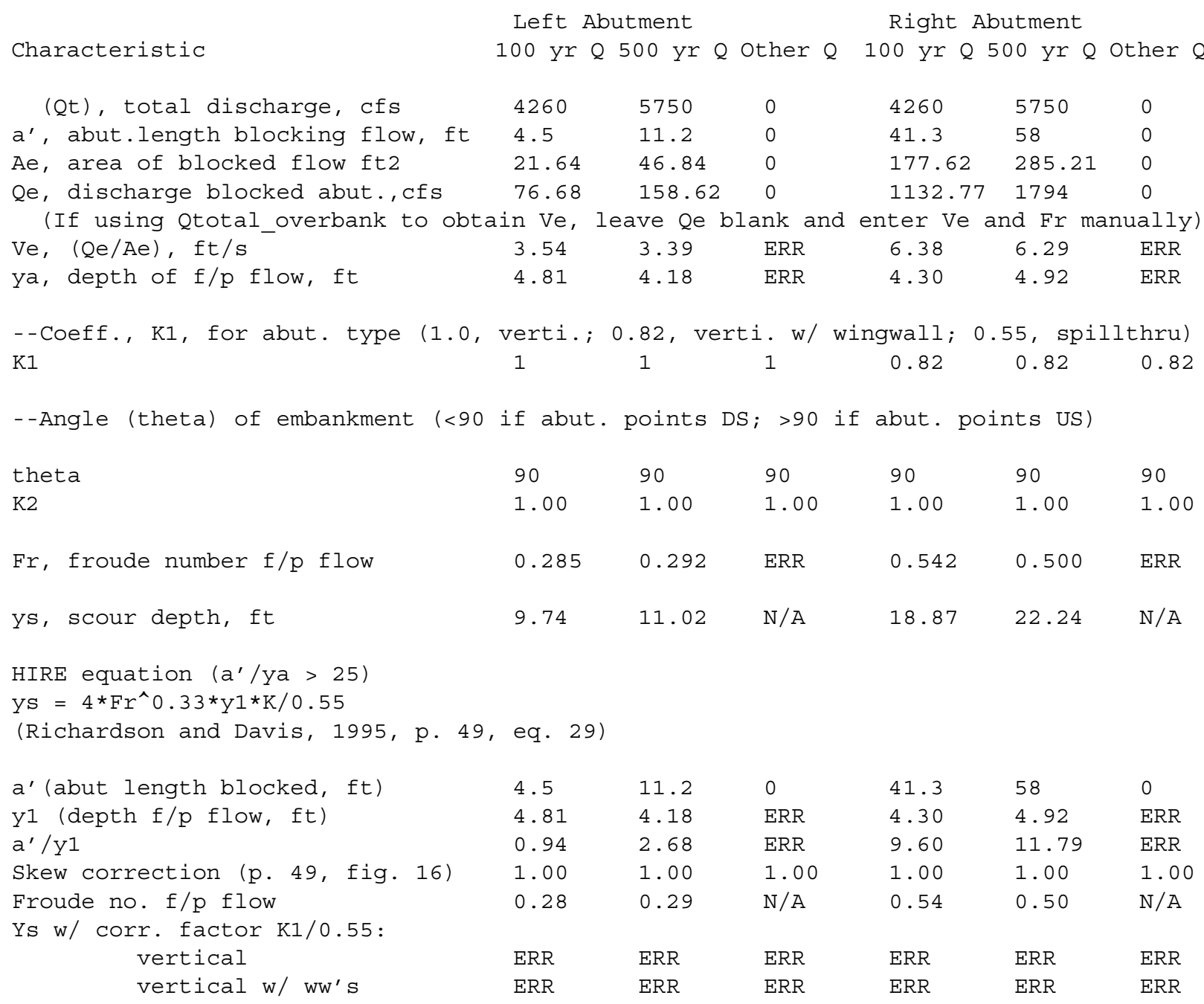




\begin{tabular}{|c|c|c|c|c|c|c|}
\hline spill-through & ERR & ERR & ERR & ERR & ERR & ERR \\
\hline \multicolumn{7}{|l|}{ Abutment riprap Sizing } \\
\hline \multirow{2}{*}{\multicolumn{7}{|c|}{$\begin{array}{l}\text { Isbash Relationship } \\
\mathrm{D} 50=\mathrm{Y}^{\star} \mathrm{K} * \mathrm{Fr} \mathrm{F}^{\wedge} /(\mathrm{Ss}-1) \text { and } \mathrm{D} 50=\mathrm{Y}^{*} \mathrm{~K} *\left(\mathrm{Fr} r^{\wedge} 2\right)^{\wedge} 0.14 /(\mathrm{Ss}-1) \\
\text { (Richardson and Davis, 1995, p112, eq. 81,82) }\end{array}$}} \\
\hline & & & & & & \\
\hline Characteristic & Q100 & Q500 & Other $Q$ & Q100 & Q500 & Other $Q$ \\
\hline Fr, Froude Number & 0.94 & 1 & 0 & 0.94 & 1 & 0 \\
\hline$y$, depth of flow in bridge, ft & 6.93 & 7.90 & 0.00 & 6.93 & 7.90 & 0.00 \\
\hline \multicolumn{7}{|c|}{ Median Stone Diameter for riprap at: left abutment } \\
\hline Fr $<=0.8$ (vertical abut.) & ERR & ERR & 0.00 & ERR & ERR & 0.00 \\
\hline Fr>0.8 (vertical abut.) & 2.85 & 3.30 & $\mathrm{ERR}$ & 2.85 & 3.30 & $\mathrm{ERR}$ \\
\hline
\end{tabular}

